\title{
Four Species of Dulichiidae (Crustacea: Amphipoda) from Japan, with the Description of a New Genus and Two New Species
}

\author{
Hiroyuki Ariyama \\ Osaka Museum of Natural History, 1-23 Nagai-koen, Higashisumiyoshi-ku, Osaka 546-0034, Japan \\ E-mail:ariyamah@rinku.zaq.ne.jp \\ (Received 15 October 2018; Accepted 29 March 2019)
}

http://zoobank.org/7287B998-E838-400C-94C7-B66C21FF35FE

\begin{abstract}
Four species of the family Dulichiidae (Crustacea: Amphipoda) are described from Japan. The first species is Dulichia biarticulata Hirayama and Takeuchi, 1993, which is characterized by the 2-articulate accessory flagellum and the expanded basis of the pereopod 4. The occurrence of this species from Miyagi-Osaka Prefectures and Fukui Prefecture is the first record from localities other than the type locality, and the morphological characters of the female are also described for the first time. The second species, Dulichia latimana sp. nov., was collected from the Ariake Sea and Sagami Bay. In this species, the male has a robust gnathopod 2 with a short proximal projection on the propodus and the slightly expanded basis of the pereopod 4. The third species is Dulichiopsis barnardi Laubitz, 1977 from off Fukushima Prefecture, which has the eyes composed of many dispersed ommatidia, the propodi of the pereopods 5-7 with a palm and the uropod 2 outer ramus about half length of the inner ramus. The morphological characters of the male are firstly described. The last species is Metadulichia kohtsukai gen. nov., sp. nov. from Sagami Bay. This species can be distinguished by the small maxilla 1 with 7 terminal robust setae on the outer plate, the maxilla 2 inner plate bearing single mediofacial seta, and the extremely short outer ramus of the uropod 2. A key to Japanese species of the family is provided.
\end{abstract}

Key Words: Dulichia, Dulichiopsis, Metadulichia, new genus, new species, new record, Dulichiidae, Amphipoda, Crustacea, Japan.

\section{Introduction}

The amphipod family Dulichiidae was established by Dana (1849). Afterward Stebbing (1906) included it into the family Podoceridae Leach, 1814; however, Myers and Lowry (2003) reinstated it with a new classification of the suborder Corophiidea ( $=$ the infraorder Corophiida at present; Lowry and Myers 2017). This family is characterized by (1) cylindrical body, (2) triangular or rectangular head, (3) slender mandibular palp, (4) glandular pereopods 3, 4, (5) fused pereonites $6,7,(6)$ urosomite 1 longer than pleonite $2+3$, and (7) absence of uropod 3 (Laubitz 1983). Six genera and 27 species have been hitherto described in this family (Horton et al. 2018): Dulichia Krøyer, 1845 [6 species]; Dulichiopsis Laubitz, 1977 [8 species]; Dyopedos Bate, 1857 [9 species]; Paradulichia Boeck, 1871 [2 species]; Paradyopedos Andres and Rauschert, 1990 [1 species]; Pseudodulichia Rauschert, 1990 [1 species]. In Japanese waters, Dulichia sp. was firstly recorded from Hokkaido (Ishimaru 1985), and Dulichia biarticulata Hirayama and Takeuchi, 1993 was described from Matsukawa-ura Inlet, Fukushima Prefecture (Hirayama and Takeuchi 1993). On the ecology of the dulichiid amphipods, an interesting behavior, mast-constructing and dwelling on the mast, is known in several species (e.g., McCloskey 1970; Mattson and Cedhagen 1989; Nii and Aoki 2005; Neretin et al. 2017; Corbari and Sorbe 2018).
In a new survey of the amphipod fauna in Japan, four species of Dulichiidae were obtained; two of them are new to science, one is new to Japan and one is newly recorded from localities other than the type locality. Herein their morphological characters are described in detail, and a key to Japanese species of the family is provided. Body length was measured from the apex of the rostrum along the dorsal margin to the distal end of the telson (excluding the connecting part between the pleonite 3 and the urosomite 1). The material examined is deposited in the Osaka Museum of Natural History (OMNH), Osaka, Japan.

\section{Systematics}

Family Dulichiidae Dana, 1849

[Japanese name: Shakutoridoronomi-ka]

Genus Dulichia Krøyer, 1845

[Japanese name: Shakutoridoronomi-zoku]

Dulichia Krøyer, 1845: 521; Laubitz 1977: 944; Laubitz 1983: 80; Barnard and Karaman 1991: 657; Myers and Lowry 2003: 470 .

Type species. Dulichia spinosissima Krøyer, 1845, by monotypy. 


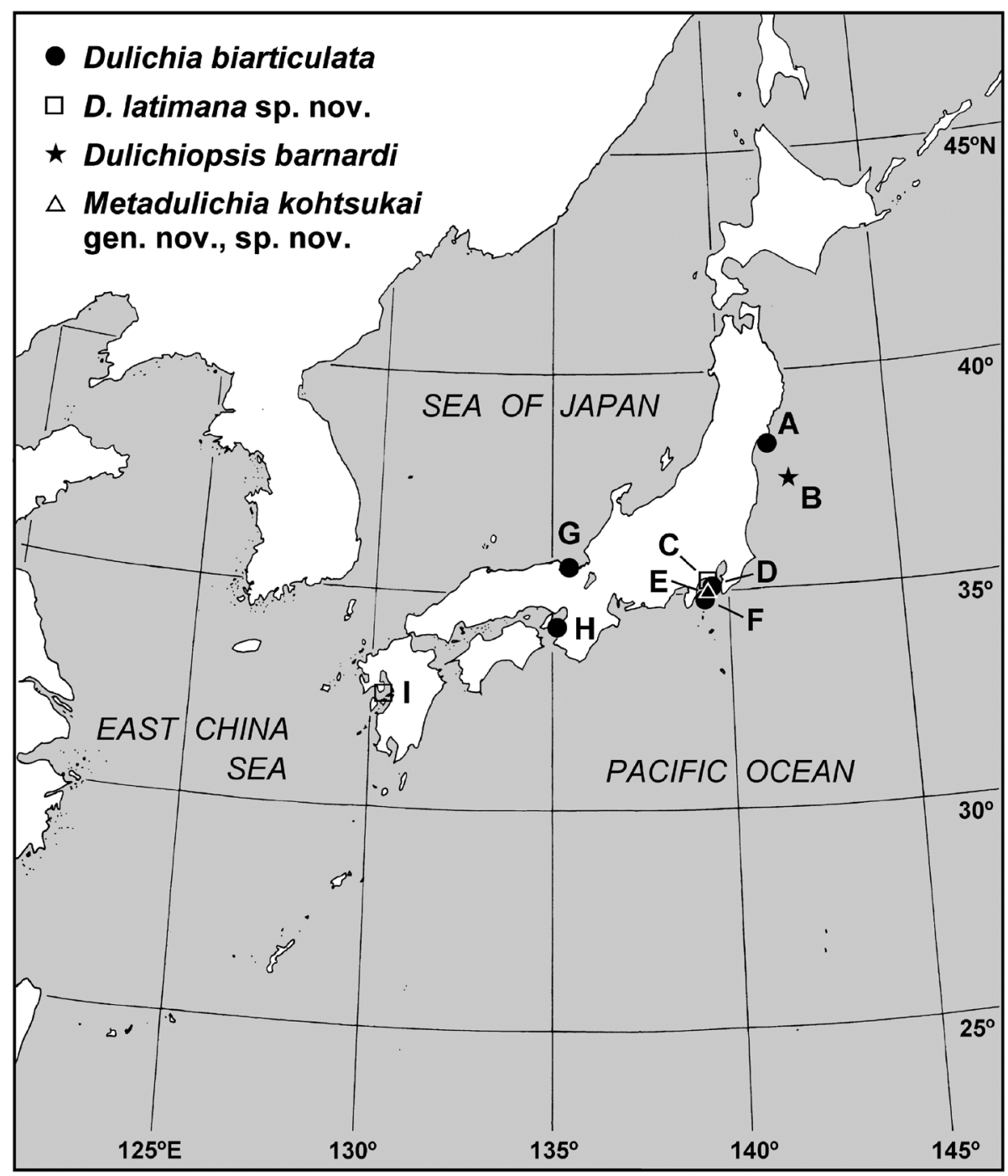

Fig. 1. Map showing the collecting sites. A, Kitsunezaki-hama, Ishinomaki City in Miyagi Prefecture; B, off Namie Town in Fukushima Prefecture; C, Sagami Bay, southwest of Miura City in Kanagawa Prefecture; D, Moroiso, Miura City in Kanagawa Prefecture; E, Sagami Bay, southwest of Miura City in Kanagawa Prefecture; F, Akinohama Beach, Izu Oshima Island in Tokyo Prefecture; G, Kodomari, Takahama Town in Fukui Prefecture; H, Tanigawa, Misaki Town in Osaka Prefecture; I, Ariake Sea.

Emended diagnosis. Body subcylindrical, but urosomites depressed dorsoventrally; pereonites 6, 7 fused; urosomites flexed beneath posterior pereonites and pleonites $1-3$, urosomite 1 elongate, urosomites 2, 3 coalesced, shorter than urosomite 1. Head triangular, rostrum well developed; eyes large, prominently convex. Antennae elongate, slender; antenna 1 peduncular articles 2, 3 much longer than article 1 , accessory flagellum 2- or 3-articulate; antenna 2 shorter than antenna 1, peduncular articles 4, 5 long. Upper lip broad, fleshy, ventral margin indented and setose. Mandible, molar developed; palp with 3 articles, article 2 longest, article 3 rectolinear. Lower lip with well-developed inner lobes, outer lobes each with mandibular lobe, covered with thin setae apically. Maxilla 1 , inner plate short, triangular, without setae; outer plate bearing 9 terminal robust setae; palp 2 -articulate, with several robust setae at tip. Maxilla 2 inner plate with mediofacial row of setae. Maxilliped inner plate with 3-4 short robust setae; outer plate not reaching apex of palp article 2, with marginal robust setae; palp consisting of
4 articles, article 4 with long stout seta. Coxae small, short, discontiguous; gills present on coxae 2-5; oostegites of female present on coxae $2-4$. Gnathopod 1 weakly subchelate, rather simple; carpus longer than propodus, propodus slender. Male gnathopod 2 enlarged, subchelate; carpus much shorter than propodus, propodus dilated, posterior margin usually with proximal and distal projections, palm oblique, dactylus long. Female gnathopod 2 smaller than that of male, subsimilar to gnathopod 1, subchelate; carpus shorter than or subequal to propodus, palm oblique. Pereopods 3, 4 short, subsimilar to each other; basis slender or expanded, glandular. Pereopods 5-7 greatly elongate, similar to each other, progressively longer; basis linear, propodus without palm, dactylus short. Pleopods large, each with developed peduncle. Uropods 1, 2 slender, biramous, uropod 1 longer than uropod 2, peduncles of both uropods shorter than both rami, outer rami shorter than inner rami; uropod 3 absent. Telson entire, ovate, longer than broad.

Included species. Dulichia biarticulata Hirayama and 
Takeuchi, 1993; D. falcata (Bate, 1857); D. latimana sp. nov.; D. rhabdoplastis McCloskey, 1970; D. spinosissima Krøyer, 1845; D. tuberculata Boeck, 1871; D. wolff Laubitz, 1977.

Remarks. Laubitz (1977) wrote "pereopods 3 and 4 bases not expanded" as the character of this genus; however in the two Dulichia species, D. biarticulata and D. rhabdoplastis (also in D. latimana sp. nov. as stated below), the basis of the male pereopod 4 is more or less expanded (McCloskey 1970; Hirayama and Takeuchi 1993).

Dulichia biarticulata Hirayama and Takeuchi, 1993 (Figs 2-5)

[Japanese name: Kishi-shakutoridoronomi, new]

Dulichia biarticulata Hirayama and Takeuchi, 1993: 160, figs $15,16$.

Material examined. Two males (OMNH-Ar-10798, 10799), 3.1 and $2.4 \mathrm{~mm}$, and female (OMNH-Ar-10800), $2.7 \mathrm{~mm}$, Kitsunezaki-hama, Ishinomaki City, Miyagi Prefecture, $38^{\circ} 21^{\prime} 21^{\prime \prime} \mathrm{N}, 141^{\circ} 25^{\prime} 23^{\prime \prime} \mathrm{E}$ (Fig. 1A), $3 \mathrm{~m}$ depth, rocky reef, using SCUBA, 3 October 2017, coll. M. Aoki; male (OMNH-Ar-10801), $3.1 \mathrm{~mm}$, Akinohama Beach, Izu Oshima Island (Oshima Town), Tokyo Prefecture, $34^{\circ} 47^{\prime} 13^{\prime \prime} \mathrm{N}$, $139^{\circ} 24^{\prime} 31^{\prime \prime E}$ (Fig. 1F), $8 \mathrm{~m}$ depth, rocky reef, using SCUBA, 4 May 2017, coll. O. Hoshino; male (OMNH-Ar-10802), $4.8 \mathrm{~mm}$, same place, 6 May 2017, coll. O. Hoshino; male (OMNH-Ar-10803), $2.9 \mathrm{~mm}$, and 2 ovigerous females
(OMNH-Ar-10804, 10805), 4.8 and $3.5 \mathrm{~mm}$, same place, 9 May 2017, coll. O. Hoshino; male (OMNH-Ar-10806), $3.5 \mathrm{~mm}$, Moroiso, Miura City, Kanagawa Prefecture (Fig. 1D), $3 \mathrm{~m}$ depth, rocky reef, using SCUBA, 25 December 2014, coll. H. Kohtsuka; 2 males (OMNH-Ar-10807, 10808), 3.8 and $2.1 \mathrm{~mm}$, and female (OMNH-Ar-10809), $2.7 \mathrm{~mm}$, Kodomari, Takahama Town, Fukui Prefecture, 3532' $10^{\prime \prime} \mathrm{N}$, $135^{\circ} 30^{\prime} 56^{\prime E}$ (Fig. 1G), $10 \mathrm{~m}$ depth, among a brown alga Sargassum macrocarpum, using SCUBA, 29 February 1980, coll. H. Ariyama and H. Nakahara; male (OMNH-Ar-10810), $2.8 \mathrm{~mm}$, same place, 25 April 1980, coll. H. Ariyama and H. Nakahara; male (OMNH-Ar-10811), $2.8 \mathrm{~mm}$, Tanigawa, Misaki Town, Osaka Prefecture, $34^{\circ} 19^{\prime} 25^{\prime \prime} \mathrm{N}, 135^{\circ} 07^{\prime} 10^{\prime \prime} \mathrm{E}$ (Fig. $1 \mathrm{H}$ ), $5 \mathrm{~m}$ depth, on a tunicate Halocynthia ritteri (Oka, 1906), using SCUBA, 29 May 1996, coll. H. Ariyama.

Diagnosis. Eyes large, round. Accessory flagellum 2-articulate. Maxilla 1 outer plate bearing 9 terminal robust setae. Maxilla 2 inner plate with mediofacial row of setae. Male gnathopod 2, basis relatively wide, propodus large, posterior margin weakly setose, bearing proximal and distal projections changeable with growth. Pereopod 4 basis expanded. Pereopod 7 carpus about 1.4 times as long as propodus. Uropod 2 outer ramus about 0.8 times length of inner ramus.

Description of male [based on male (OMNH-Ar-10801), $3.1 \mathrm{~mm}$ ]. Body (Fig. 2), dorsal margins of pereonites and pleonites smooth, urosomite 1 about 1.35 times as long as pleonites $2+3$. Eyes round, about 0.3 times length of head.

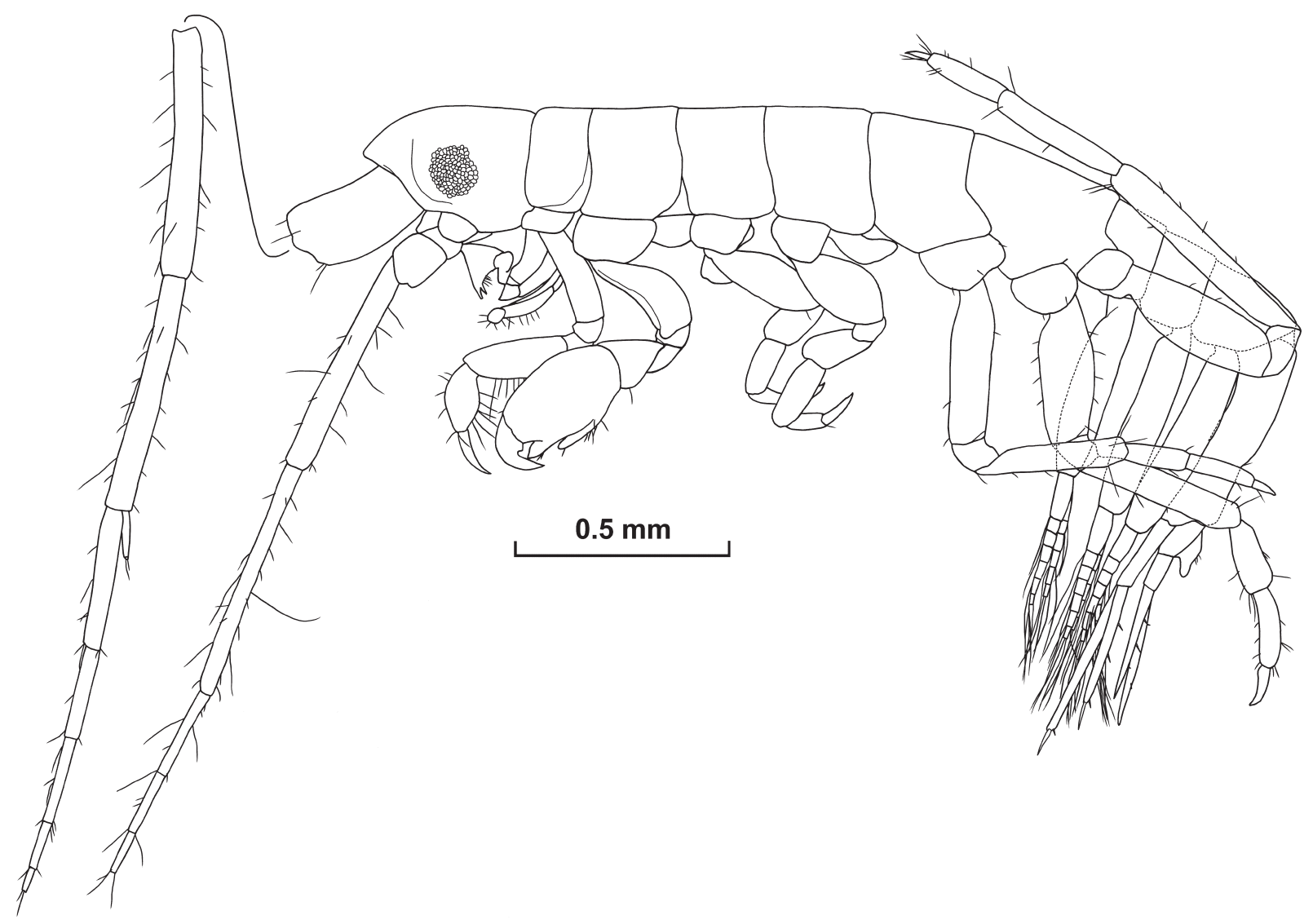

Fig. 2. Dulichia biarticulata Hirayama and Takeuchi, 1993. Male (OMNH-Ar-10801), $3.1 \mathrm{~mm}$. Habitus, left lateral view. 
Antenna 1 (Figs 2, 3A) about 0.8 times as long as body, accessory flagellum 2-articulate. Antenna 2 (Fig. 2) about 0.7 times length of antenna 1.

Gnathopod 1 (Fig. 3B), basis with ridge on anterolateral surface; merus setose posterodistally; carpus with many setae on posterior margin; propodus with many setae posteriorly, medial surface also setose; dactylus curved posteriorly. Gnathopod 2 (Fig. 3C), coxa wide, larger than coxa 1, subtrapezoidal, ventral margin slightly excavated; basis relatively wide, anterodistal corner a little lobate; carpus triangular, posterodistal corner setose; propodus large, about 0.7 times as long as head, about 2.1 times length of carpus, posterior margin weakly setose, bearing distally-oriented proximal projection and distal projection each with minute setae; dactylus stout, posterior margin produced proximally.

Pereopod 3 (Fig. 3D, E), basis weakly expanded, about 2.2 times as long as width, with glands in most part; merus short. Pereopod 4 (Fig. 3D, F) longer than pereopod 3; basis strongly expanded, about 1.6 times as long as width, with glands in central part; merus longer than that of pereopod 3. Pereopod 5 (Fig. 3G, G1), basis slender, merus short, carpus about 0.85 times as long as propodus. Pereopod 6 (Fig. $3 \mathrm{H}$ ) about 1.1 times length of pereopod 5; basis slightly expanded, merus short, carpus about 0.9 times as long as propodus. Pereopod 7 (Fig. 3H, I) about 1.3 times length of pereopod 6; basis slightly expanded, merus long, carpus about 1.4 times as long as propodus.

Description of female [based on female (OMNHAr-10805), $3.5 \mathrm{~mm}$ ]. Gnathopod 1 (Fig. 4A) similar to that of male. Gnathopod 2 (Fig. 4B, B1), coxa narrower than male coxa 2, trapezoidal; basis straight, anterodistal corner not lobate; carpus pear-shaped, posterior margin heavily setose; propodus about 1.25 times as long as carpus, palm with single robust seta, posterior margin and medial surface setose; dactylus slender. Pereopods 3, 4 (Fig. 4C, D) almost same as those of male, bases weakly expanded, about 2.3 and 1.9 times as long as width respectively.

Variation. Gnathopod 2: propodi and dactyli in very large male (OMNH-Ar-10802, $4.8 \mathrm{~mm}$; Fig. 4E) and large male (OMNH-Ar-10807, $3.8 \mathrm{~mm}$; Fig. 4F) longer than those of male (OMNH-Ar-10801, $3.1 \mathrm{~mm}$; Fig. 3C), proximal projections of propodi also long and situated more proximally, right-angled to palm in very large male and at about $45^{\circ}$ angle to palm in large male; propodi and dactyli in male (OMNH-Ar-10803, $2.9 \mathrm{~mm}$; Fig. 4G) and small male (OMNH-Ar-10808, $2.1 \mathrm{~mm}$; Fig. $4 \mathrm{H}$ ) almost same as those of male (OMNH-Ar-10801, $3.1 \mathrm{~mm}$; Fig. 3C). Pereopod 3: bases in very large male (OMNH-Ar-10802, $4.8 \mathrm{~mm}$ ) and large male (OMNH-Ar-10807, $3.8 \mathrm{~mm}$ ) slender, about 4.1 and 3.45 times as long as width respectively. Pereopod 4: bases in those males weakly expanded, about 2.6 and 2.35 times as long as width respectively.

Coloration in life (Fig. 5). Eyes dark red; dorsal part of body pale brown, ventrolateral part of body beige, scattered with small brown pigments; distal part of peduncular article 3 and proximal part of flagellar article 1 of male antenna 1 white. Whole body except for eyes orange in some large females.
Remarks. The morphological characters of the specimens are very similar to those of the original descriptions and figures of Dulichia biarticulata. Although Hirayama and Takeuchi (1993) stated "in pereopods 5 and 7, propodi clearly longer than carpi”, the fig. 16P (lower) in their paper is not the left pereopod 7 and the fig. $16 \mathrm{O}$ (upper and lower) is also not the left pereopod 6. The figs $16 \mathrm{P}$ (lower) and $16 \mathrm{O}$ are probably the left pereopod 6 and the right pereopod 7 , respectively; therefore, the propodus of the pereopod 7 is shorter than the carpus like my specimens. Hirayama and Takeuchi (1993) described this species based on the male specimen. Morphological characters of the female were firstly described in the present paper.

Habitat. Found on the self-constructed mast on rocky reef (Fig. 5), on tunicates or among algae, 3-10 $\mathrm{m}$ depth.

Distribution. Japan: coasts of Miyagi, Fukushima, Tokyo, Kanagawa, Fukui and Osaka Prefectures (Hirayama and Takeuchi 1993, present study).

\section{Dulichia latimana sp. nov.}

(Figs 6-10)

[Japanese name: Oki-shakutoridoronomi, new]

Material examined. Holotype: male (OMNH-Ar-10812), $5.1 \mathrm{~mm}$, Ariake Sea, southeast of Minami-shimabara City, Nagasaki Prefecture, $32^{\circ} 39^{\prime} 01^{\prime \prime N}, 130^{\circ} 23^{\prime} 01^{\prime \prime} \mathrm{E}$ (St. AG16, Fig. 1I), $50 \mathrm{~m}$ depth, sandy bottom, using SmithMcIntyre grab, 12 May 2006, coll. K. Mori. Paratypes: male (OMNH-Ar-10813), $4.9 \mathrm{~mm}$, same data as holotype; 3 males (OMNH-Ar-10814-10816), 5.9, 4.4 and $4.3 \mathrm{~mm}$, and 2 ovigerous females (OMNH-Ar-10817, 10818), 5.4 and $4.7 \mathrm{~mm}$, Ariake Sea, northwest of Ōyano Island, Kumamoto Prefecture, $32^{\circ} 37^{\prime} 01^{\prime \prime N}, 130^{\circ} 23^{\prime} 01^{\prime \prime E}$ (St. AG17, Fig. 1I), $58 \mathrm{~m}$ depth, sandy bottom, using Smith-McIntyre grab, 15 May 2006, coll. K. Mori; male (OMNH-Ar-10819), $3.0 \mathrm{~mm}$, ovigerous female (OMNH-Ar-10820), $3.3 \mathrm{~mm}$, and female (OMNH-Ar-10821), $2.2 \mathrm{~mm}$, Sagami Bay, southwest of Miura City, Kanagawa Prefecture, $35^{\circ} 07^{\prime} 35^{\prime \prime N}$, $139^{\circ} 33^{\prime} 43^{\prime \prime E}-35^{\circ} 07^{\prime} 33^{\prime \prime} \mathrm{N}, 139^{\circ} 33^{\prime} 00^{\prime \prime E}$ (Fig. 1C), 102-111 m depth, using dredge, 26 April 2016, coll. H. Kohtsuka; male (OMNH-Ar-10822), $2.0 \mathrm{~mm}$, Sagami Bay, southwest of Miura City, Kanagawa Prefecture, $35^{\circ} 09^{\prime} 09^{\prime N} \mathrm{~N}$, $139^{\circ} 34^{\prime} 50^{\prime \prime E}-35^{\circ} 08^{\prime} 57^{\prime \prime} \mathrm{N}, 139^{\circ} 34^{\prime} 00^{\prime \prime E}$ (Fig. 1C), 76-80 m depth, using dredge, 26 April 2016, coll. H. Kohtsuka.

Diagnosis. Eyes large, round. Maxilla 1 outer plate bearing 9 terminal robust setae. Maxilla 2 inner plate with mediofacial row of setae. Male gnathopod 2, basis widened distally, propodus robust, posterior margin weakly setose, with short proximal and distal projections. Pereopod 4 basis slightly expanded. Pereopod 7 carpus about 1.9 times length of propodus. Uropod 2 outer ramus about 0.85 times as long as inner ramus.

Description of male [based mostly on holotype (OMNHAr-10812), $5.1 \mathrm{~mm}$, supplemented by paratype (OMNHAr-10813), $4.9 \mathrm{~mm}$ for coxa 1 and paratype (OMNHAr-10819), $3.0 \mathrm{~mm}$ for antennae and pereopods 6, 7]. Body (Fig. 6), dorsal margins of pereonites and pleonites weakly corrugated, urosomite 1 about 1.35 times length of pleonites 


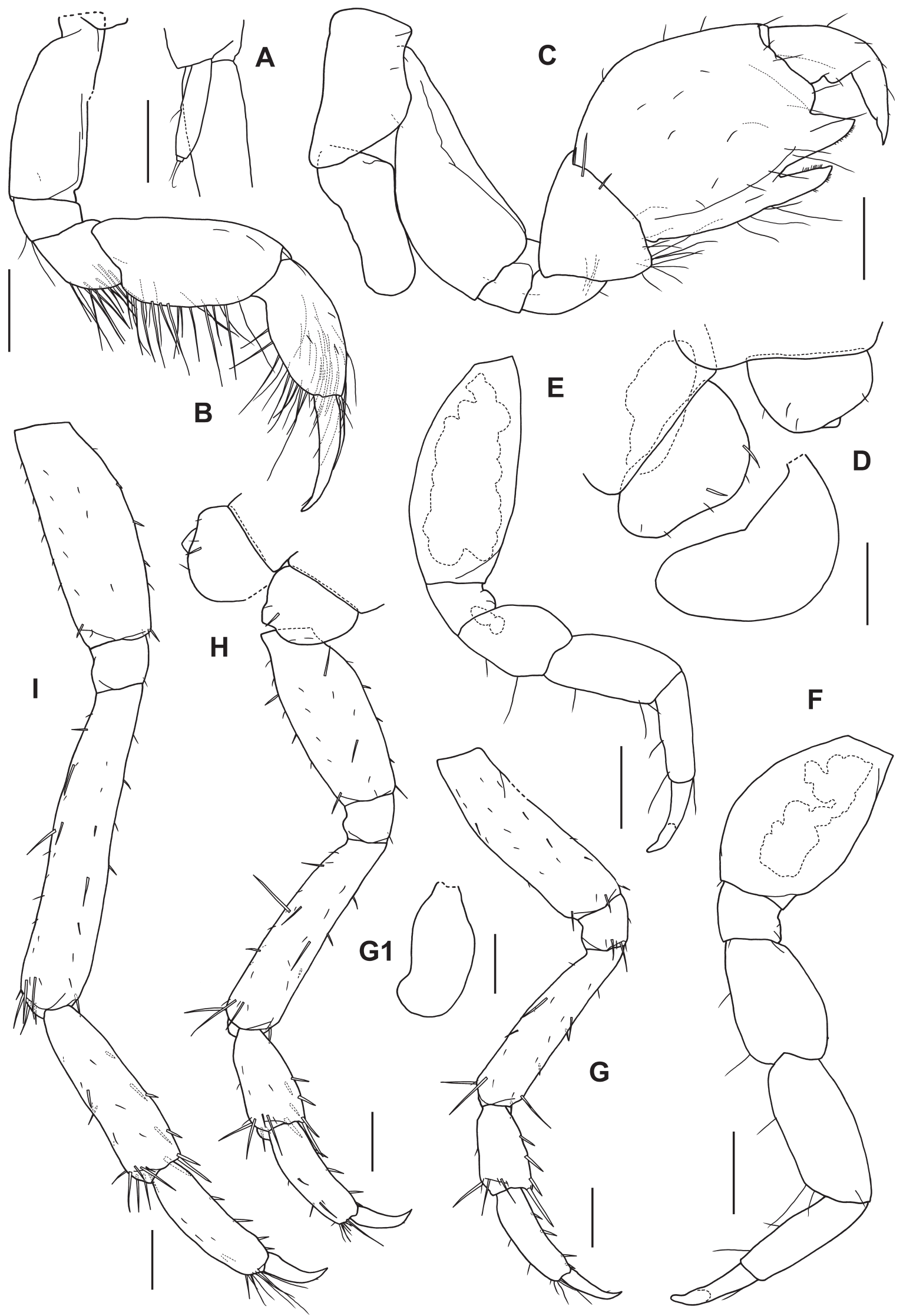

Fig. 3. Dulichia biarticulata Hirayama and Takeuchi, 1993. Male (OMNH-Ar-10801), $3.1 \mathrm{~mm}$. A, accessory flagellum of right antenna 1, medial view; B, C, right gnathopods 1, 2, lateral views; D, right coxae 3, 4 and gills, lateral view; E-G, right pereopods 3-5, lateral views; G1, right gill 5, lateral view, coxa lost; $\mathrm{H}$, right coxae 6, 7 and pereopod 6, lateral view; I, right pereopod 7, lateral view. Scales: $0.1 \mathrm{~mm}$. 


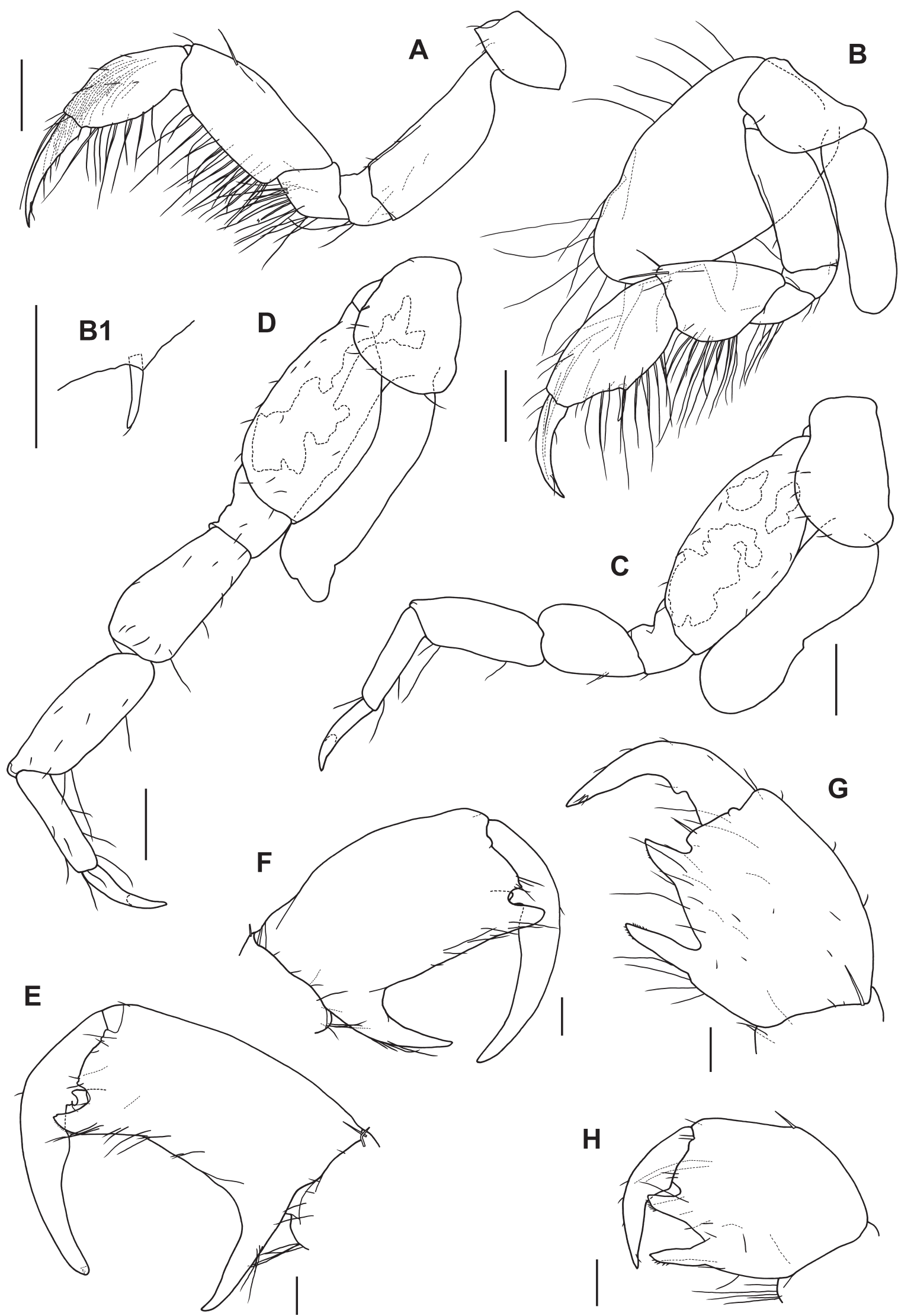

Fig. 4. Dulichia biarticulata Hirayama and Takeuchi, 1993. A-D, B1, ovigerous female (OMNH-Ar-10805), $3.5 \mathrm{~mm}$; E, very large male (OMNH-Ar-10802), $4.8 \mathrm{~mm}$; F, large male (OMNH-Ar-10807), $3.8 \mathrm{~mm}$; G, male (OMNH-Ar-10803), $2.9 \mathrm{~mm}$; H, small male (OMNHAr-10808), $2.1 \mathrm{~mm}$. A, B, left gnathopods 1, 2, lateral views; B1, robust seta on left gnathopod 2 palm, lateral view, slender setae omitted; C, D, left pereopods 3, 4, lateral views, oostegites omitted; E, G, H, propodi and dactyli of left gnathopods 2, lateral views; F, propodus and dactylus of right gnathopod 2, lateral view. Scales: $0.1 \mathrm{~mm}$. 


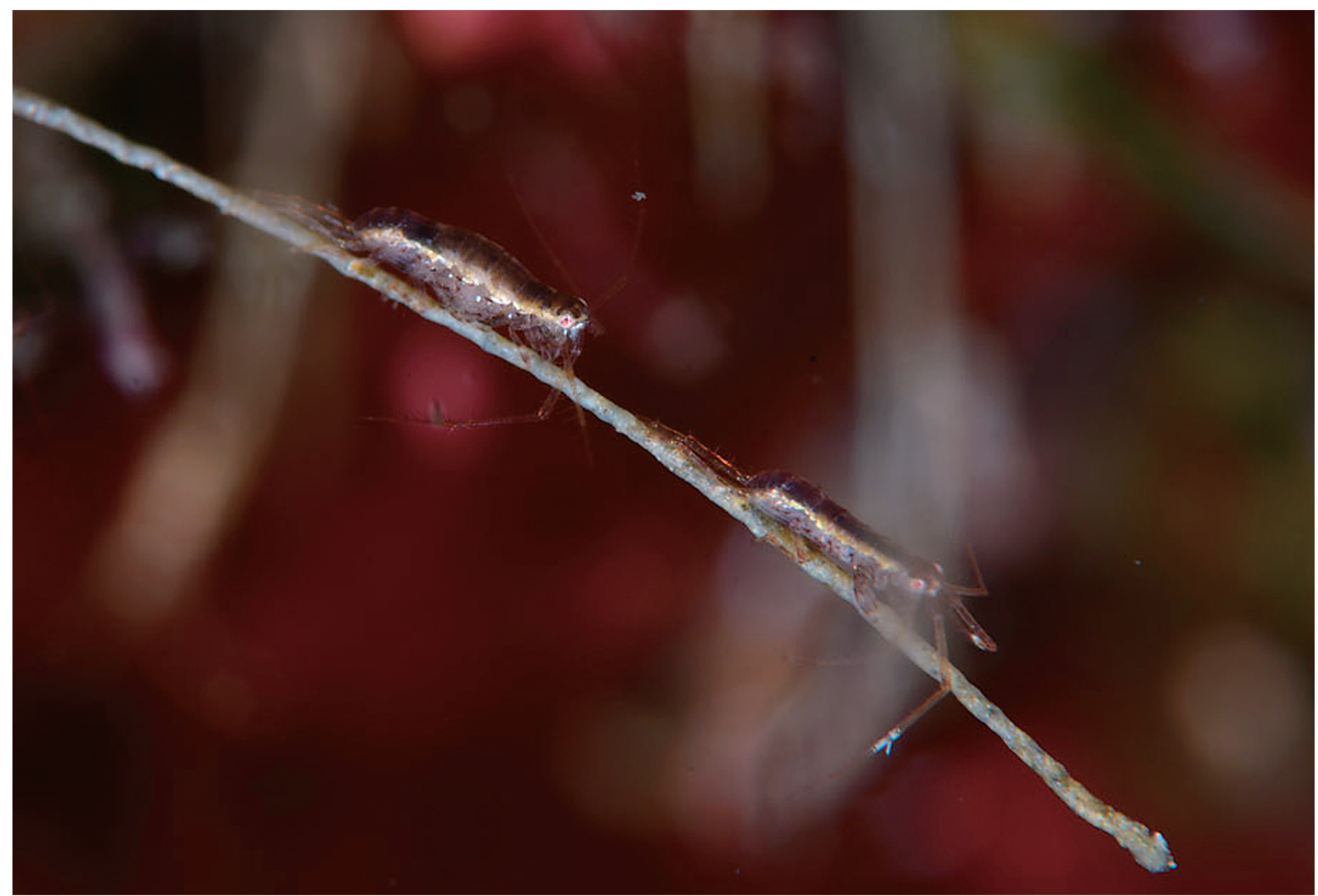

Fig. 5. Dulichia biarticulata Hirayama and Takeuchi, 1993. In situ photograph of a male and a female taken on Akinohama Beach, Izu Oshima Island ( $8 \mathrm{~m}$ depth) on 6 May 2017 by O. Hoshino.

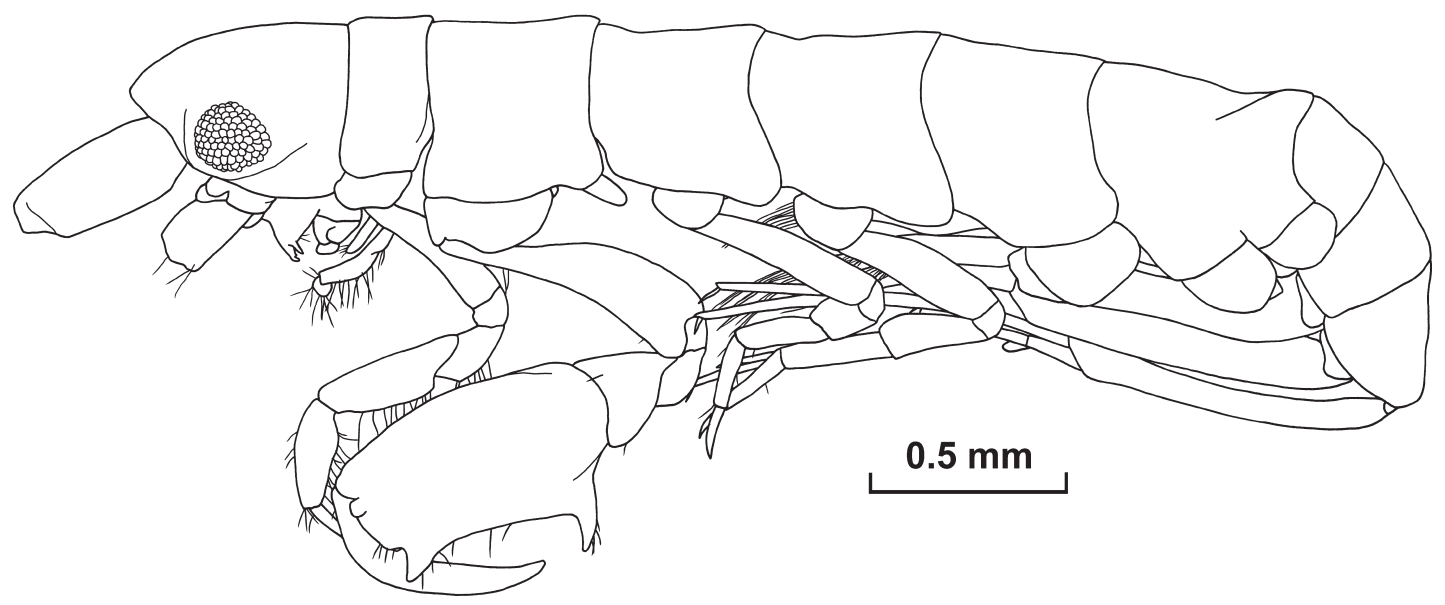

Fig. 6. Dulichia latimana sp. nov. Holotype, male (OMNH-Ar-10812), $5.1 \mathrm{~mm}$. Habitus, left lateral view, most of antennae and pereopods 5-7 lost.

$2+3$. Eyes round, about one third length of head.

Antenna 1 [Figs 7A, 10; most parts lost in all specimens, but remained when taking photograph in paratype, male (OMNH-Ar-10819), $3.0 \mathrm{~mm}$ ] elongate, almost same length as body; peduncular article 1 with several ventral robust setae, peduncular articles 2, 3 very long; accessory flagellum short, articulation unknown. Antenna 2 (Figs 7B, 10; same condition as antenna 1) about 0.7 times length of antenna 1; peduncular article 3 short, with several robust setae anteriorly. Upper lip (Fig. 7C) ordinary. Mandibles (Fig. 7D,
D1, E, E1) with length ratio of palp articles $1-31.0: 2.1: 1.2$, articles 2, 3 each with 6-7 setae; incisor with 7 and 6 cusps, lacinia mobilis with 4 and 2 cusps in left and right, respectively, 4 and 3 accessory blades present in left and right, respectively; molar with spatula-like process in right. Lower lip (Fig. 7F) ordinary. Maxilla 1 (Fig. 7G, G1), palp article 2 bearing 5-6 robust setae apically and several setae dorsally. Maxilla 2 (Fig. 7H), inner plate with distal setae, very thin laterodistal setae and 10 mediofacial setae, outer plate bearing many setae on distal margin. Maxilliped (Fig. 7I), inner 


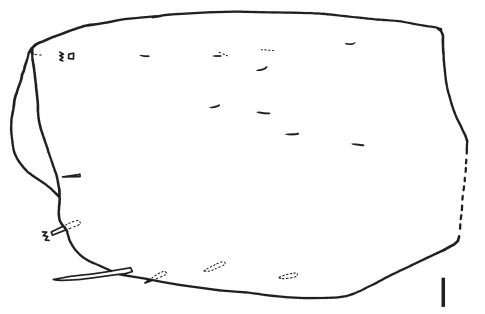

A
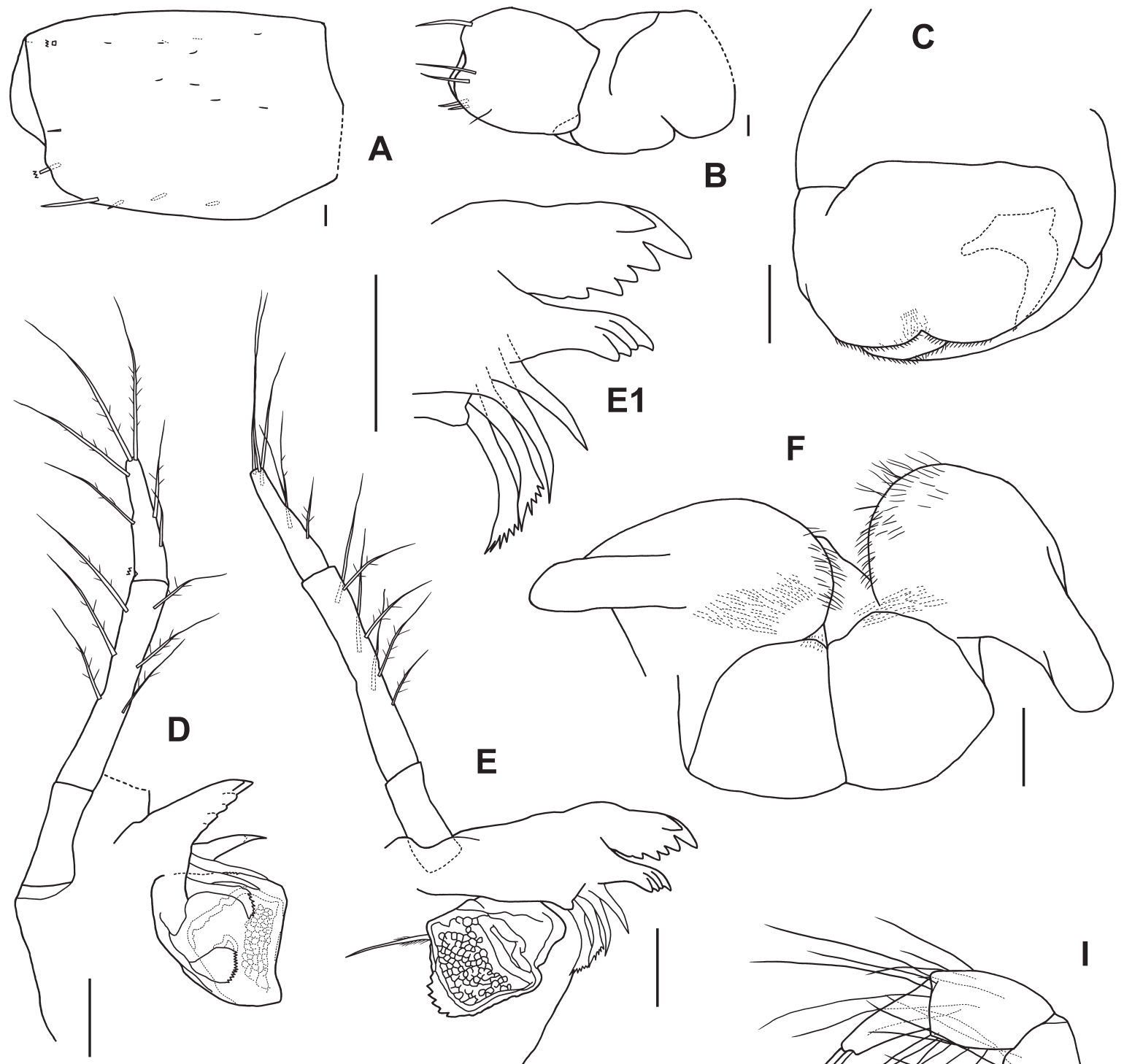

B
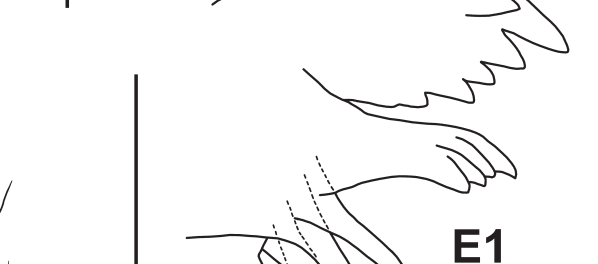

E1
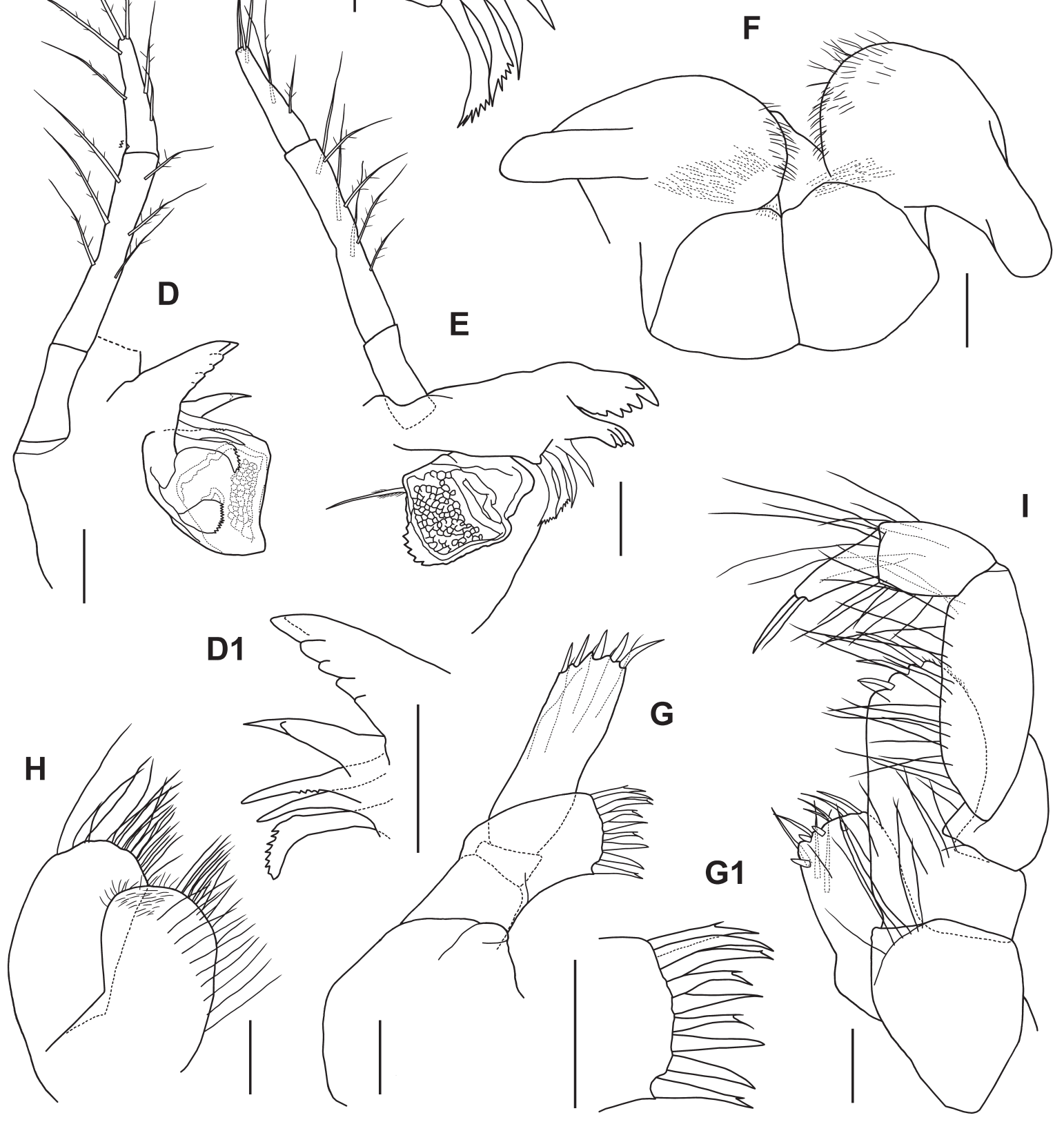

Fig. 7. Dulichia latimana sp. nov. Holotype, male (OMNH-Ar-10812), $5.1 \mathrm{~mm}$. A, left antenna 1, lateral view, peduncular article 1 only; B, left antenna 2, lateral view, peduncular articles 1-3 only; C, upper lip, anterior view; D, right mandible, lateral view; D1, incisor, lacinia mobilis and accessory blades of right mandible, medial view; E, left mandible, medial view; E1, incisor, lacinia mobilis and accessory blades of left mandible, medial view; F, lower lip, ventral view; G, left maxilla 1, dorsomedial view; G1, distal part of outer plate of left maxilla 1, dorsomedial view; $\mathrm{H}$, left maxilla 2, dorsal view; I, left maxilliped, ventral view. Scales: $0.05 \mathrm{~mm}$. 
B
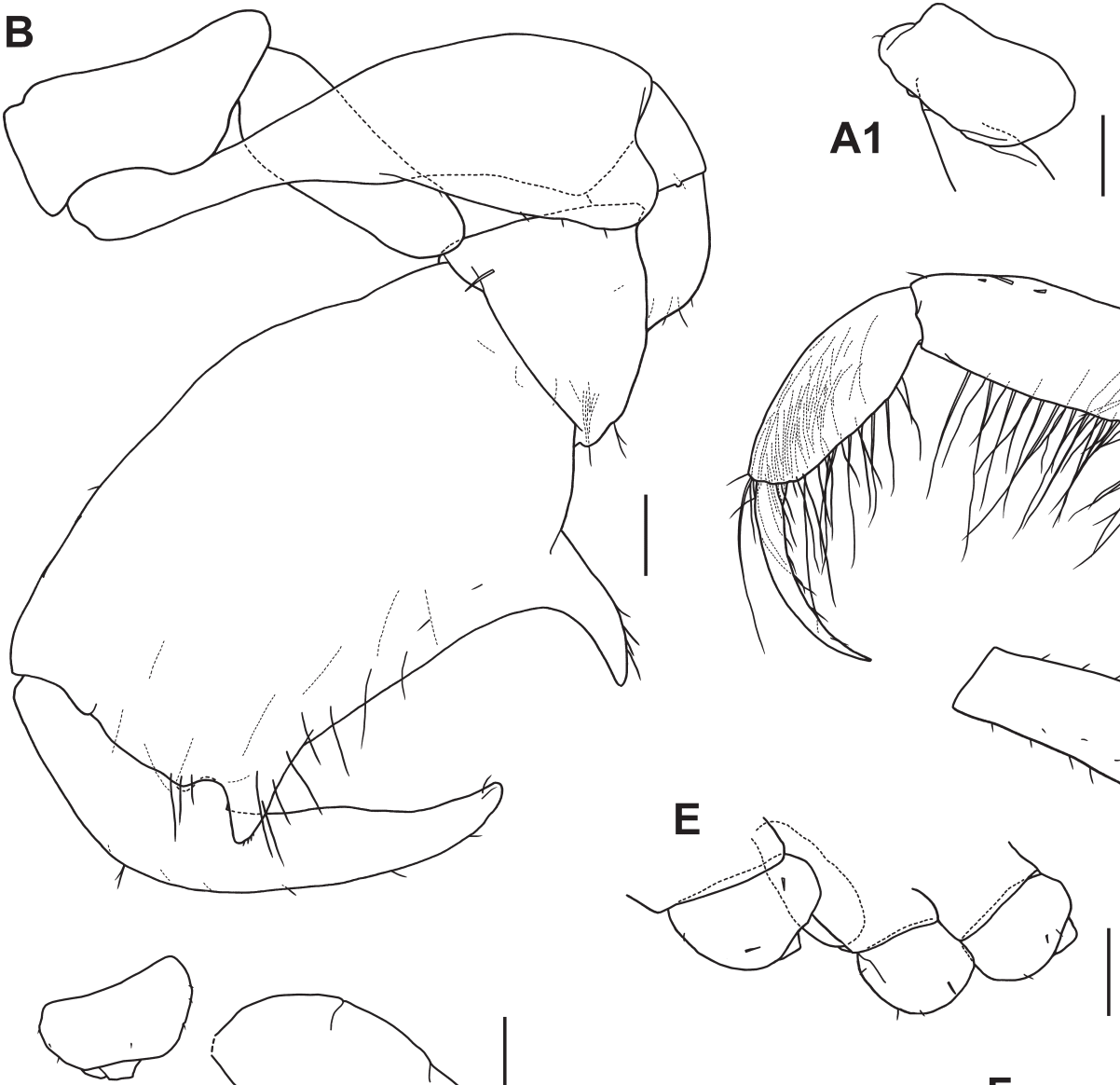

C1
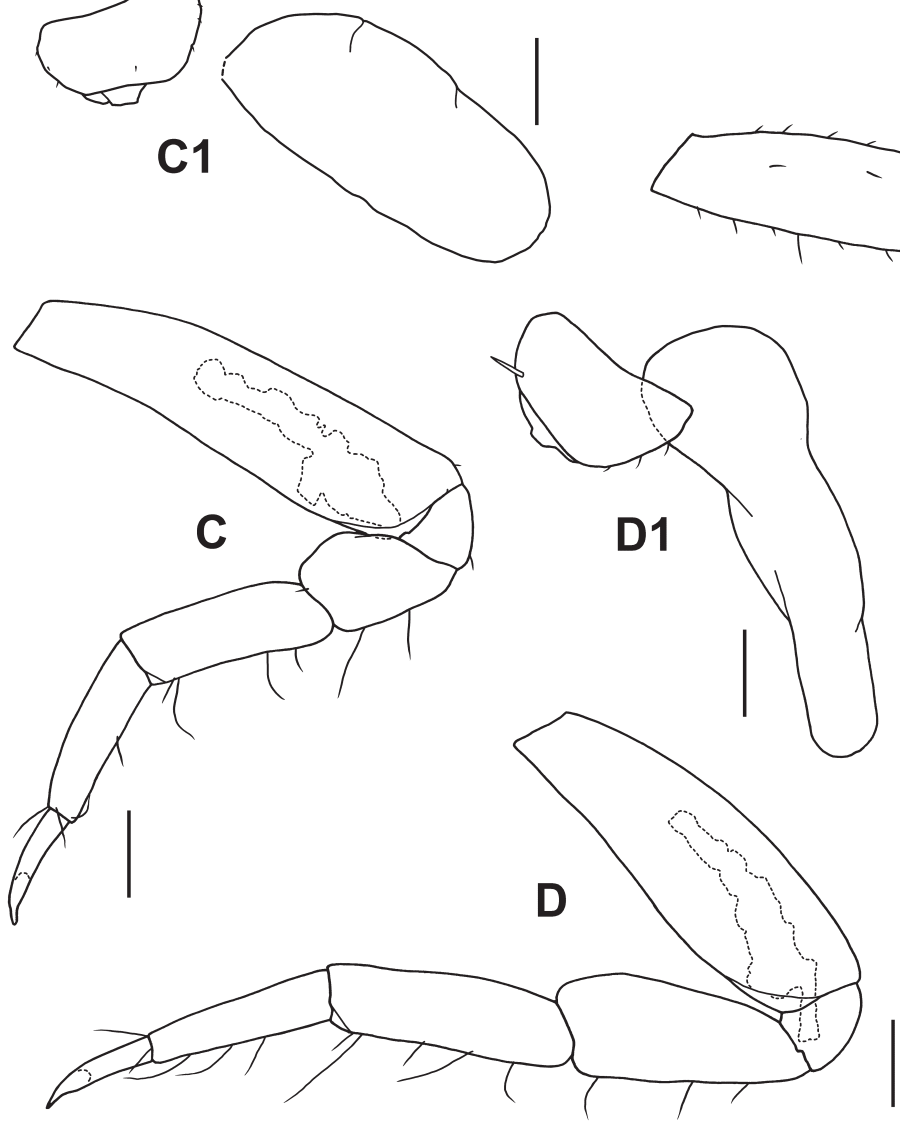

$\mathbf{F}$
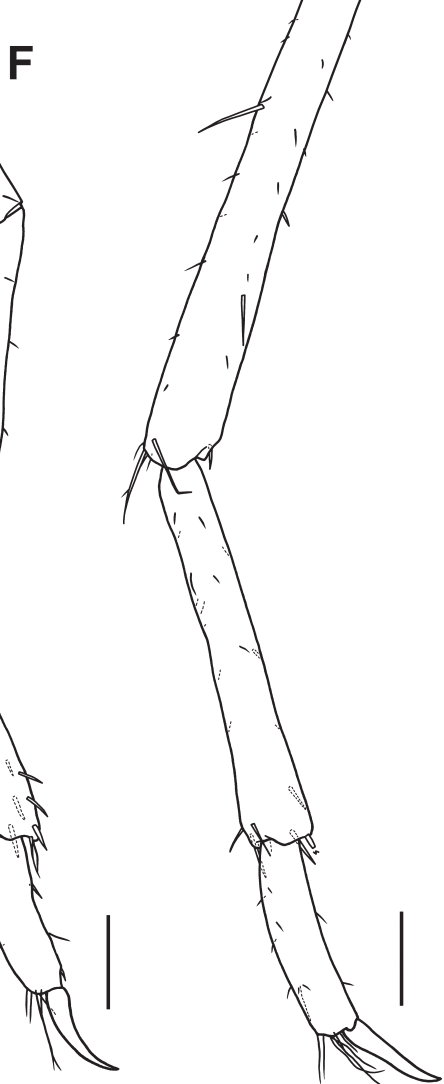

Fig. 8. Dulichia latimana sp. nov. A-D, C1, D1, holotype, male (OMNH-Ar-10812), $5.1 \mathrm{~mm}$; A1, paratype, male (OMNH-Ar-10813), $4.9 \mathrm{~mm}$; E-G, paratype, small male (OMNH-Ar-10819), $3.0 \mathrm{~mm}$. A, B, left gnathopods 1, 2, lateral views; A1, left coxa 1, lateral view; C, D, left pereopods 3, 4, lateral views; C1, D1, left coxae 3, 4 and gills, lateral views; E, left coxae 5-7 and gill 5, lateral view; F, G, right pereopods 6,7 , lateral views. Scales: $0.1 \mathrm{~mm}$. 


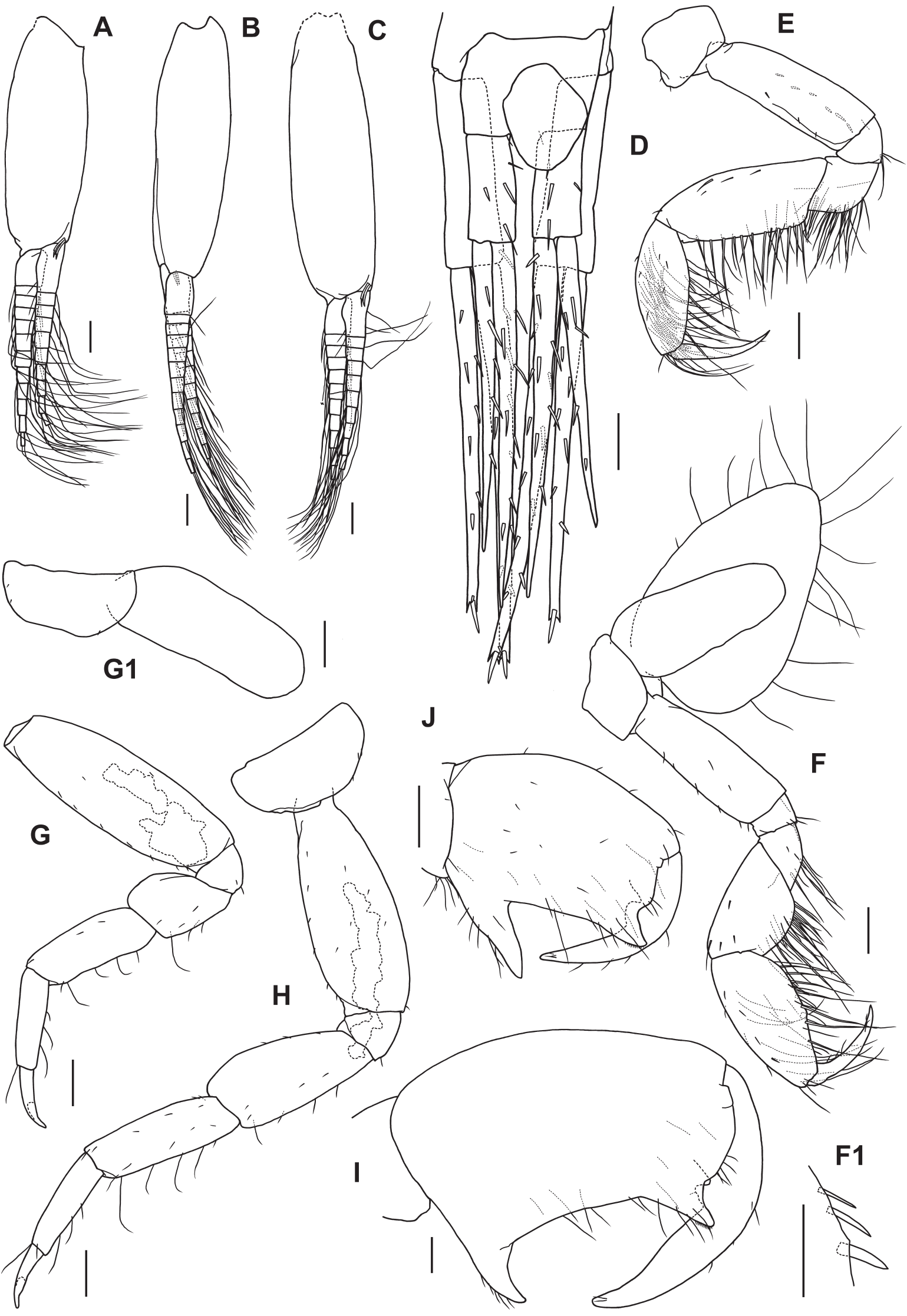

Fig. 9. Dulichia latimana sp. nov. A-D, holotype, male (OMNH-Ar-10812), $5.1 \mathrm{~mm}$; E-H, F1, G1, paratype, ovigerous female (OMNHAr-10817), $5.4 \mathrm{~mm}$; I, paratype, large male (OMNH-Ar-10814), $5.9 \mathrm{~mm}$; J, paratype, small male (OMNH-Ar-10819), 3.0 mm. A, C, left pleopods 1, 3, medial views; B, left pleopod 2, lateral view; D, uropods 1, 2 and telson, dorsal view; E, F, left gnathopods 1, 2, lateral views; F1, robust setae on left gnathopod 2 palm, lateral view, slender setae omitted; G, left pereopod 3, lateral view; G1, left coxa 3 and gill, lateral view; $\mathrm{H}$, left pereopod 4, lateral view, gill lost; I, J, propodi and dactyli of right gnathopods 2, lateral views. Scales: $0.1 \mathrm{~mm}$. 


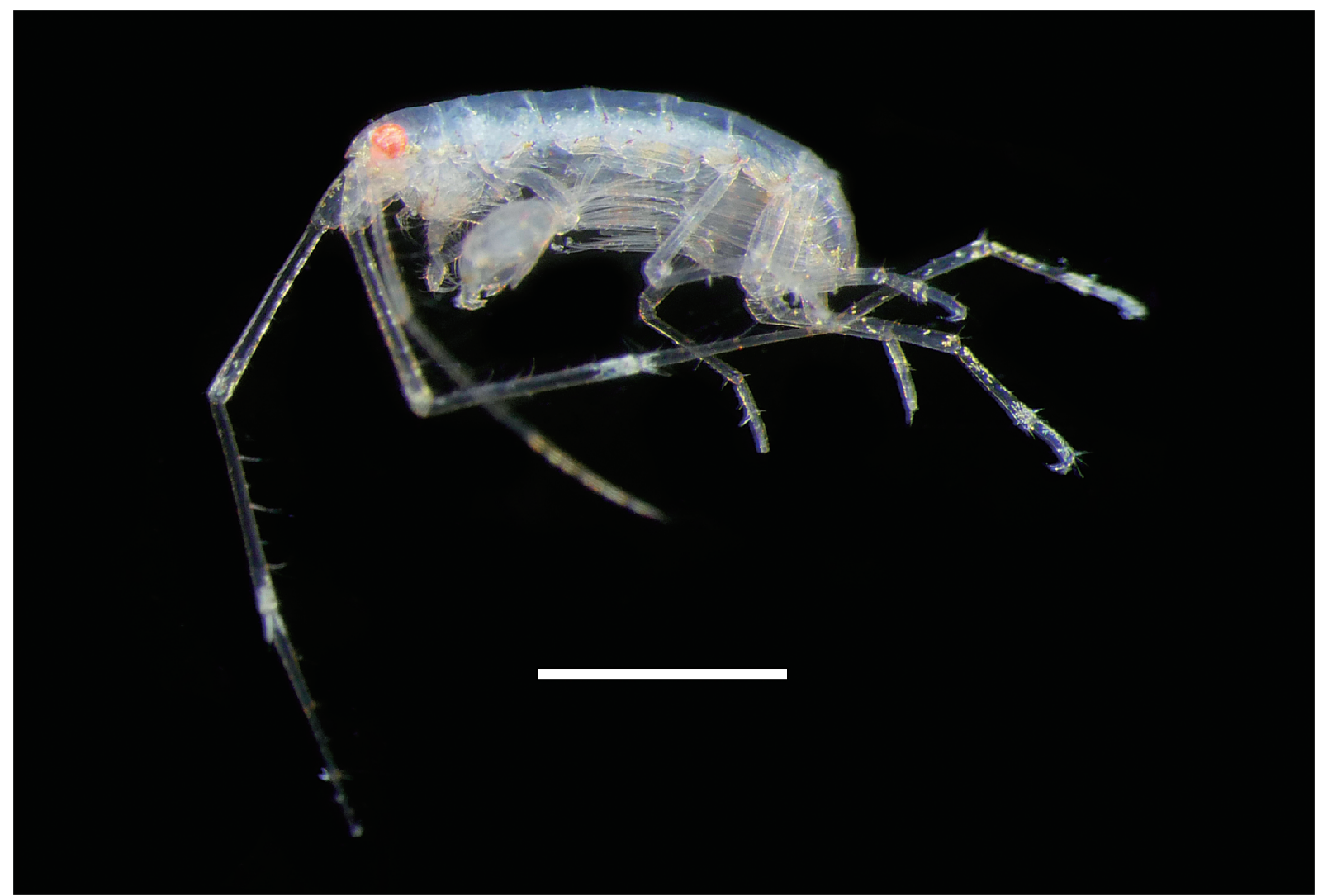

Fig. 10. Dulichia latimana sp. nov. Photograph of paratype, male (OMNH-Ar-10819), $3.0 \mathrm{~mm}$ by H. Kohtsuka, live specimen. Scale: $1 \mathrm{~mm}$. Antennae and pereopod 5 lost after photographing.

plate with 3 apical and 1 mediodistal short robust setae on ventral surface; outer plate bearing 3 slender robust setae mediodistally.

Gnathopod 1 (Fig. 8A, A1) slender; coxa subrectangular; basis with ridge on anterolateral surface, bearing single robust seta medially; merus setose posterodistally and mediodistally; carpus long, with many setae on posterior margin; propodus with many setae posteriorly, medial surface heavily setose; dactylus long, slender, curved posteriorly. Gnathopod 2 (Fig. 8B) robust; coxa wide, subtrapezoidal, ventral margin slightly excavated; basis widened distally, curved anteriorly, anterodistal corner roundly lobate; carpus triangular, weakly setose; propodus long and wide, about 1.2 times as long as head, about 3.2 times length of carpus, posterior margin weakly setose, with proximal projection at about $80^{\circ}$ angle to palm and small distal projection, posteroproximal margins of both projections bearing several short setae and several minute setae, respectively; dactylus stout, posterior margin roundly produced proximally.

Pereopod 3 (Fig. 8C, C1), coxa semicircular, gill large; basis slender, about 3.8 times as long as width, with glands in middle to distal parts; merus short. Pereopod 4 (Fig. 8D, D1) longer than pereopod 3; coxa semicircular, gill large; basis slightly expanded, about 2.9 times as long as width, with glands in middle to distal parts; merus longer than that of pereopod 3. Pereopod 5 (Figs 8E, 10; same condition as antenna 1) much longer than pereopod 4, slender; gill small. Pereopod 6 (Fig. 8E, F), merus long, carpus almost same length as propodus. Pereopod 7 (Fig. 8E, G) about 1.35 times length of pereopod 6; merus very long, carpus about 1.9 times as long as propodus.

Pleopods (Fig. 9A-C), peduncles progressively longer, each with 2 slender coupling hooks; outer rami slightly longer than inner rami, outer rami with $12,12,11$ articles and inner rami with 10,11, 10 articles respectively. Uropod 1 (Fig. 9D), peduncle with mediodistal robust seta; outer ramus about 0.9 times as long as inner ramus, outer ramus with 4 lateral, 3 medial and 1-2 terminal robust setae, inner ramus bearing 2-3 lateral, 6 medial and 1-2 terminal robust setae. Uropod 2 (Fig. 9D) about 0.8 times length of uropod 1 ; peduncle with 1 lateral and 3 medial robust setae; outer ramus about 0.85 times as long as inner ramus in left, outer ramus with 2 lateral and 3 medial robust setae, inner ramus bearing 3 lateral and 4 medial robust setae. Telson (Fig. 9D) bare.

Description of female [based on paratype (OMNHAr-10817), $5.4 \mathrm{~mm}$ ]. Gnathopod 1 (Fig. 9E) similar to that of male, but coxa narrower and medial surface of basis lined with several robust setae. Gnathopod 2 (Fig. 9F, F1), coxa narrow, trapezoidal; basis straight, anterodistal corner not lobate; carpus pear-shaped, posterior margin heavily setose; propodus about 1.25 times as long as carpus, palm with 3 robust setae, posterior margin and medial surface setose; dactylus slender. Pereopods 3, 4 (Fig. 9G, G1, H) same as those of male, but basis of pereopod 3 slightly expanded.

Variation. Gnathopod 2: propodus and dactylus in large 
male [paratype (OMNH-Ar-10814), $5.9 \mathrm{~mm}$; Fig. 9I] similar to those of holotype; in small male [paratype (OMNHAr-10819), 3.0 mm; Fig. 9J], propodus shorter than that of holotype, posteroproximal projection relatively longer, at about $50^{\circ}$ angle to palm. Pereopod 3: bases in large male (OMNH-Ar-10815, 4.4 mm) and small male (OMNHAr-10819, $3.0 \mathrm{~mm}$ ) slender, about 3.85 and 4.05 times as long as width respectively. Pereopod 4: basis in large male (OMNH-Ar-10816, $4.3 \mathrm{~mm}$ ) weakly expanded, about 2.3 times as long as width; basis in small male (OMNHAr-10819, $3.0 \mathrm{~mm}$ ) slightly expanded, about 2.8 times as long as wide.

Coloration in life (Fig. 10). Eyes light red; whole body almost transparent, scattered with yellow and brown pigments; distal parts of peduncular articles 2, 3 of antenna 1 white, distal part of pereopod 7 propodus white.

Etymology. From the Latin lati (=broad) and mana (=hand), referring to the wide propodus of the male gnathopod 2.

Remarks. This new species has (1) large eyes, (2) maxilla 2 inner plate bearing mediofacial setae, (3) gills present on coxae $2-5$, (4) oostegites of female present on coxae 2-4, (5) not prehensile propodi of pereopods 6,7 (pereopod 5 unknown), and (6) long outer ramus of uropod 2. These features suggest that this species is included in the genus $D u$ lichia. Dulichia latimana sp. nov. can be distinguished from its congeners by the large propodus of the male gnathopod 2 with weakly setose palm bearing short proximal projection, the pereopod 4 with slightly or weakly expanded basis, and the long carpus of the pereopod 7.

Habitat. Sandy bottom, 50-111 m depth.

Distribution. Japan: the Ariake Sea and Sagami Bay (present study).

Genus Dulichiopsis Laubitz, 1977

[Japanese name: Shakutoridoronomi-modoki-zoku, new]

Dulichiopsis Laubitz, 1977: 951; Laubitz 1983: 80; Barnard and Karaman 1991: 659; Myers and Lowry 2003: 470.

Type species. Dulichia nordlandica Boeck,1871, by original designation.

Emended diagnosis. Body subcylindrical, but urosomites slightly depressed dorsoventrally; pereonites 6, 7 fused; urosomites flexed beneath posterior pereonites and pleonites $1-3$, urosomite 1 elongate, urosomites 2 , 3 coalesced, shorter than urosomite 1. Head more or less rectangular, rostrum small; eyes dorsally fused, weakly developed or absent. Antennae very long, slender; antenna 1 peduncular article 3 longest, accessory flagellum 3- or 4-articulate; antenna 2 slightly shorter than antenna 1 . Upper lip broad, fleshy, ventral margin bilobed. Mandible, molar developed; palp with 3 articles, article 2 longest, article 3 rectolinear. Lower lip with well-developed inner lobes, outer lobes each with short mandibular lobe. Maxilla 1, inner plate rudimentary, without setae; outer plate bearing 9 terminal robust setae; palp 2 -articulate, with several robust setae at tip. Maxilla 2 inner plate with mediofacial row of setae. Maxilliped inner plate with 2-4 short robust setae; outer plate not reaching apex of palp article 2, with marginal robust setae; palp consisting of 4 articles, article 4 with stout seta. Coxae small, short, discontiguous; gills present on coxae 2-5; oostegites of female present on coxae $2-4$. Gnathopod 1 weakly subchelate, rather simple; carpus longer than propodus, propodus weakly almond-shaped. Male gnathopod 2 powerfully developed, subchelate; carpus much shorter than propodus, propodus dilated, posterior margin usually with proximal and distal projections, palm oblique, dactylus long. Female gnathopod 2 smaller than that of male, subequal to gnathopod 1 , subchelate; carpus shorter than propodus, palm oblique. Pereopods 3, 4 short, subsimilar to each other; basis slender, glandular. Pereopods 5-7 elongate, similar to each other, progressively longer; basis linear, propodus with palm, dactylus short. Pleopods large, each with developed peduncle. Uropods 1, 2 slender, biramous, uropod 1 longer than uropod 2, peduncles of both uropods shorter than both rami, outer rami shorter than inner rami; uropod 3 absent. Telson entire, ovate, longer than broad.

Included species. Dulichiopsis abyssi (Stephensen, 1944); D. barnardi Laubitz, 1977; D. brevidactyla Ledoyer, 1986; D. cyclops (Gurjanova, 1946); D. dianae Corbari and Sorbe, 2018; D. macera (Sars, 1879); D. nordlandicus (Boeck, 1871); D. remis (Barnard, 1964).

Remarks. This genus resembles Dulichia, but is readily distinguishable in the obsolescent to absent eyes and the prehensile pereopods $5-7$.

Dulichiopsis barnardi Laubitz, 1977

(Figs 11-13)

[Japanese name: Shakutoridoronomi-modoki, new]

Dulichia remis: Barnard 1964: 332, fig. 12m-u. (non Dulichia remis Barnard, 1964)

Dulichiopsis barnardi Laubitz, 1977: 955, fig. 7.

Material examined. Male (OMNH-Ar-10823), $8.5 \mathrm{~mm}$, off Namie Town, Fukushima Prefecture, $37^{\circ} 28^{\prime} 38^{\prime \prime} \mathrm{N}$, $141^{\circ} 58^{\prime} 38^{\prime \prime E}$ (KS14-6, No. 4; Fig. 1B), 531-540 m depth, using beam trawl, 2 May 2014, coll. T. Takano.

Diagnosis. Eyes composed of many dispersed ommatidia. Maxilla 1 outer plate bearing 9 terminal robust setae. Maxilla 2 inner plate with mediofacial row of setae subdistally. Male gnathopod 2, basis widened distally, propodus massive, ovoid, posterior margin weakly setose, with large proximal projection and small distal projection. Pereopod 4 basis slender. Pereopod 5 elongate, prehensile. Urosomite 1 about 1.6 times as long as pleonites $2+3$. Uropod 2 outer ramus about half length of inner ramus.

Description of male [based on male (OMNH-Ar-10823), $8.5 \mathrm{~mm}$ ]. Body (Fig. 11), dorsal margins of pereonites and pleonites slightly corrugated, urosomite 1 about 1.6 times as long as pleonites $2+3$. Eyes round, large, about one third length of head, composed of many dispersed ommatidia.

Antenna 1 (Fig. 12A), peduncular article 1 with single ventral robust seta; peduncular articles 2, 3, accessory flagellum and primary flagellum lost. Antenna 2 (Fig. 12B), 


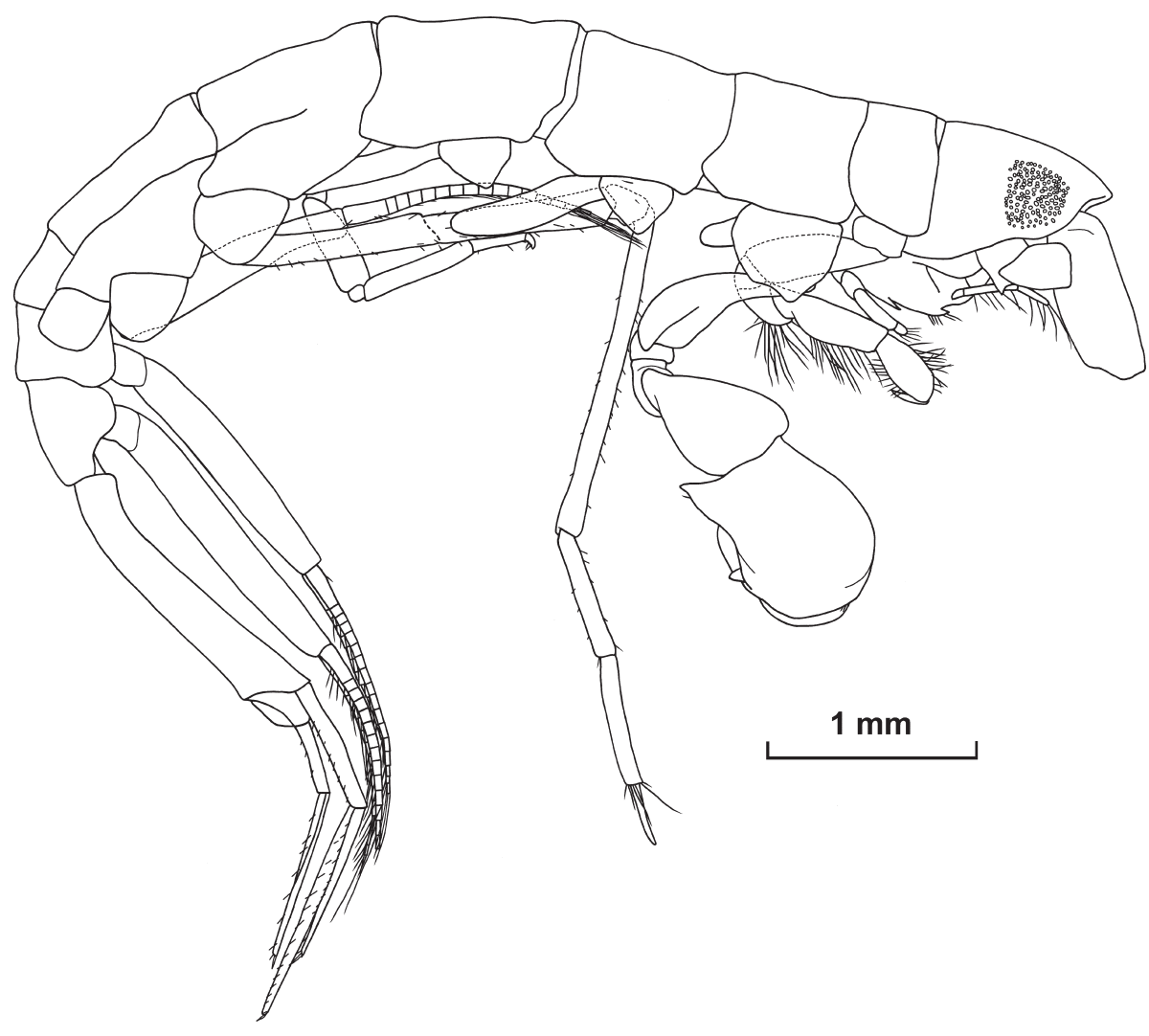

Fig. 11. Dulichiopsis barnardi Laubitz, 1977. Male (OMNH-Ar-10823), $8.5 \mathrm{~mm}$. Habitus, right lateral view; most of antennae and pereopods 3, 6, 7 lost, left pereopod 4 drawn.

peduncular article 3 short; peduncular articles 4, 5 and flagellum lost. Upper lip (Fig. 12C), ventral margin with sparse short setae. Mandibles (Fig. 12D, D1, E, E1) with length ratio of palp articles $1-31.0: 2.6: 1.6$, articles 2 and 3 with 12 and 9-10 setae, respectively; incisor with 6 cusps, lacinia mobilis with 4 and 5 cusps in left and right, respectively, 3 and 4 accessory blades present in left and right, respectively; molar with spatula-like process in right. Lower lip (Fig. $12 \mathrm{~F}$ ), outer and inner lobes covered with thin setae apically. Maxilla 1 (Fig. 12G, G1, G2), inner plate round, palp article 2 bearing 7 robust setae apically. Maxilla 2 (Fig. 12H), inner plate with distal setae and many subdistal mediofacial setae, outer plate bearing many setae on distal margin. Maxilliped (Fig. 12I), inner plate with 3 apical and 1 mediodistal short robust setae on ventral surface; outer plate bearing 10 slender robust setae mediodistally.

Gnathopod 1 (Fig. 13A) slender; coxa subrectangular; merus setose posterodistally and mediodistally; carpus long, with many setae on posterior margin and several setae on medioproximal surface; propodus densely setose posteriorly and mediodistally; dactylus long, slender, curved posteriorly, posterior margin lined with minute setae. Gnathopod 2 (Fig. 13B, B1), coxa subtrapezoidal, gill slender; basis widened distally, curved anteriorly, anterodistal corner slightly lobate, lateral surface with several sensory setae; carpus subtriangular, weakly setose; propodus massive, ovoid, about 1.5 times as long as head, about 1.55 times length of carpus, posterior margin weakly setose, with large proximally-oriented proximal projection at about $100^{\circ}$ angle to palm and small distal projection at about $35^{\circ}$ angle to palm; dactylus stout, posterior margin with small quadrate projection proximally.

Pereopod 3 (Fig. 13C), coxa triangular, gill long; other parts lost. Pereopod 4 (Fig. 13D) slender; coxa triangular, gill long; basis slender, about 4.45 times as long as width, with glands in anterior and posterior parts; merus long. Pereopod 5 (Fig. 13E, E1) about 2.0 times length of pereopod 4; coxa bearing short setae, gill short; basis and merus very long, carpus about 1.2 times as long as propodus; lateral surfaces of basis, merus and carpus with many small robust setae; propodus with palm, anterior margin lined with robust setae. Pereopods 6, 7 (Fig. 13F) lost except for coxae.

Pleopods (Fig. 13G-I), peduncles progressively longer, each with 2 slender coupling hooks; outer rami slightly longer than inner rami, outer rami with 16, 16, 15 articles and inner rami with 15, 15, 13 articles respectively. Uropod 1 (Fig. 13J), peduncle with 10 lateral and 5 medial robust setae; outer ramus about 0.7 times as long as inner ramus, outer ramus with 14 lateral and 4 medial robust setae, inner ramus bearing 13 lateral, 15 medial and 2 distal robust setae. Uropod 2 (Fig. 13J) about 0.7 times length of uropod 1; peduncle with 2 lateral and 4 medial robust setae; outer ramus about half length of inner ramus, outer ramus with 3 lateral and 2 medial robust setae, inner ramus bearing 4 lateral and 7 medial robust setae. Telson (Fig. 13J) with 4 setae dorsally.

Coloration in life. Unknown.

Remarks. Laubitz (1977) described this species based on the female specimens. The present male specimen, how- 

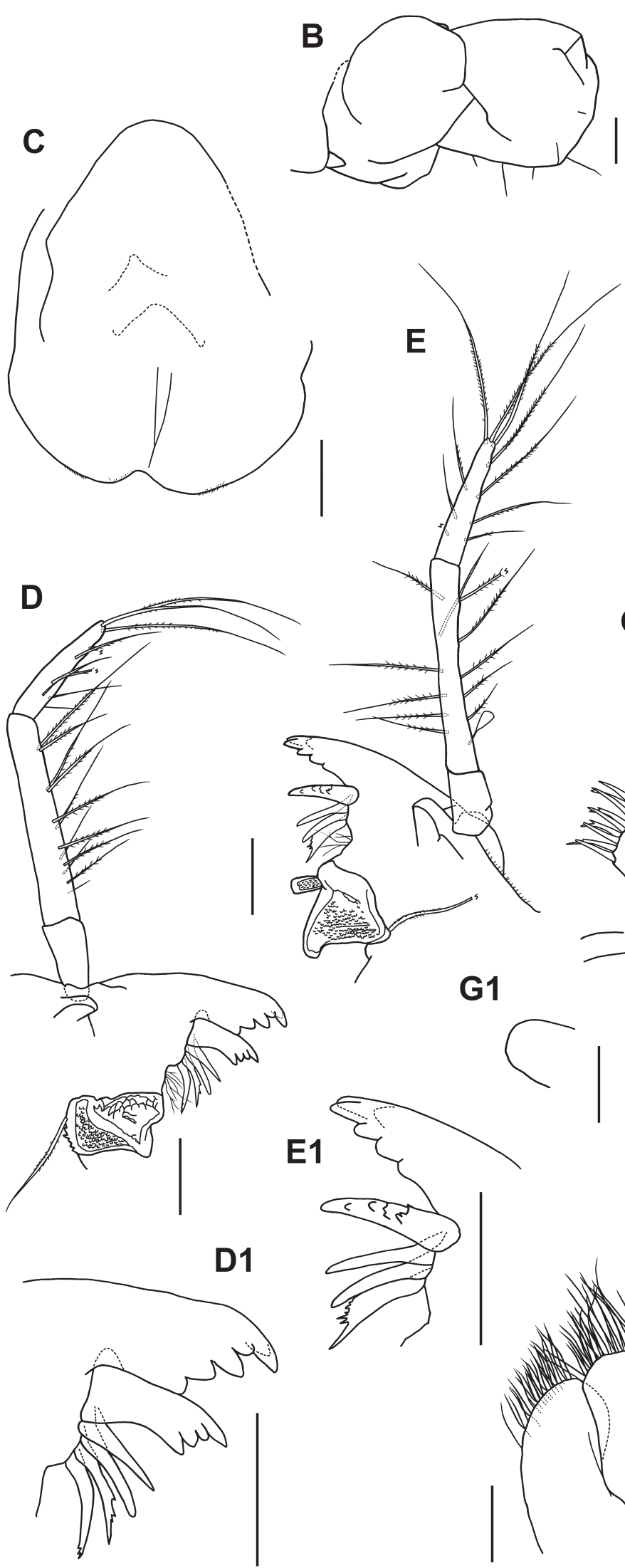

G1

E1

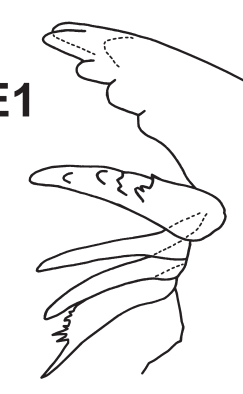<smiles>C1CCCC1</smiles>

A
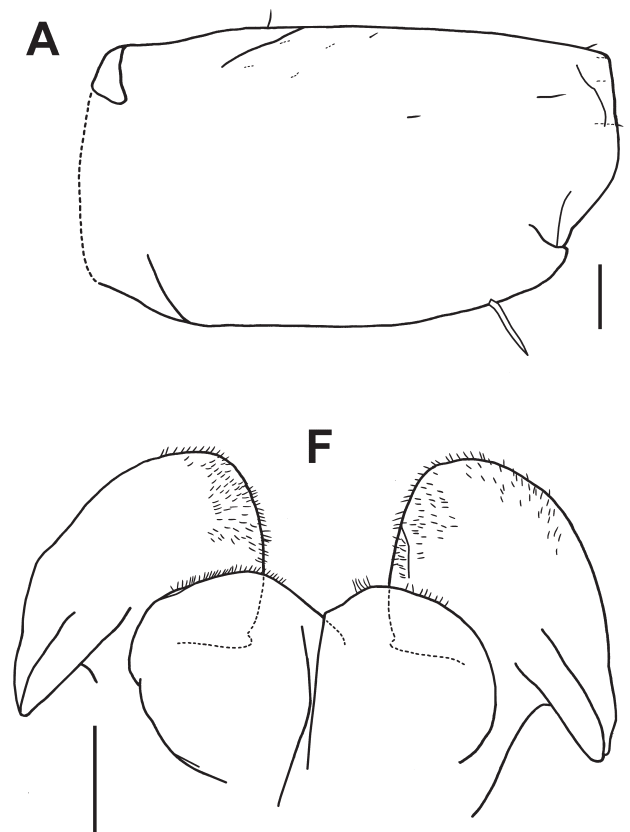

G

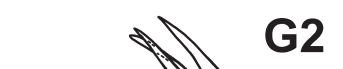

G2
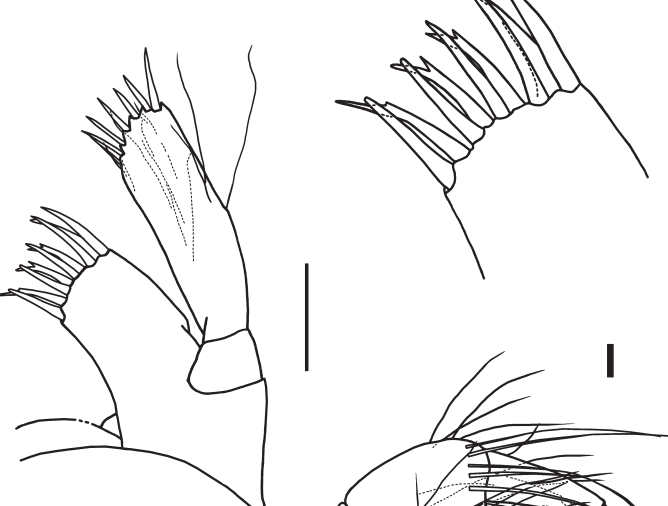

H
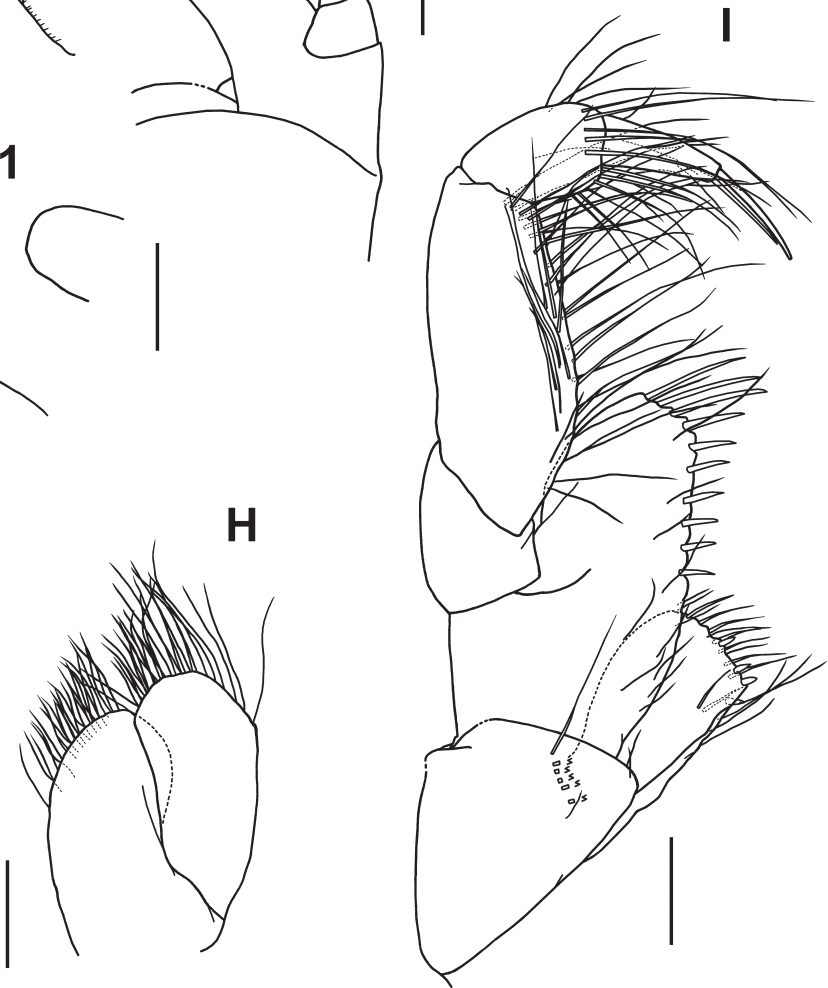

Fig. 12. Dulichiopsis barnardi Laubitz, 1977. Male (OMNH-Ar-10823), $8.5 \mathrm{~mm}$. A, right antenna 1, lateral view, peduncular article 1 only; B, right antenna 2, lateral view, peduncular articles 1-3 only; C, upper lip, anterior view; D, left mandible, medial view; D1, incisor, lacinia mobilis and accessory blades of left mandible, medial view; E, right mandible, medial view; E1, incisor, lacinia mobilis and accessory blades of right mandible, medial view; F, lower lip, ventral view; G, left maxilla 1, ventral view; G1, inner plate of right maxilla 1, dorsal view; G2, distal part of outer plate of left maxilla 1, ventral view; $\mathrm{H}$, left maxilla 2, dorsal view; I, right maxilliped, ventral view. Scales: $0.1 \mathrm{~mm}$. 


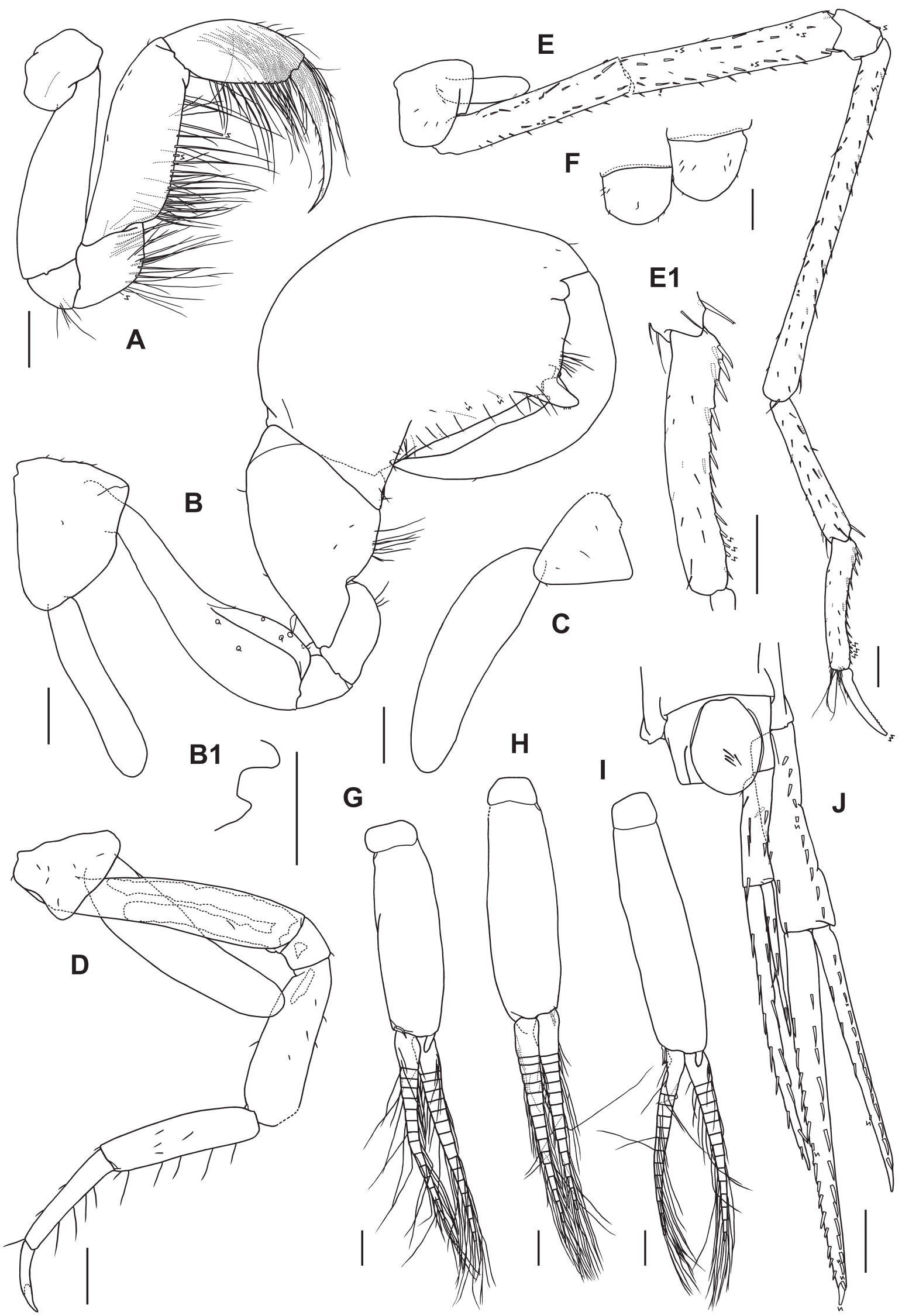

Fig. 13. Dulichiopsis barnardi Laubitz, 1977. Male (OMNH-Ar-10823), $8.5 \mathrm{~mm}$. A, B, right gnathopods 1, 2, lateral views; B1, posteroproximal part of right gnathopod 2 dactylus, lateral view; C, right coxa 3 and gill, lateral view; D, left pereopod 4, lateral view; E, right pereopod 5, lateral view; E1, propodus of right pereopod 5, lateral view, distal setae omitted; F, right coxae 6, 7, lateral view; G, I, right pleopods 1, 3, posterior views; $\mathrm{H}$, right pleopod 2, anteior view; J, right uropods 1, 2 and telson, dorsal view. Scales: $0.2 \mathrm{~mm}$. 
ever, can be identified as Dulichiopsis barnardi, because (1) the eyes are composed of many dispersed ommatidia, (2) the maxilla 2 inner plate has mediofacial setae subdistally, (3) the urosomite 1 is much longer than the pleonites $2+3$, and (4) the uropod 2 outer ramus is about half length of the inner ramus.

Habitat. Bottom sediment unknown, 531-540 m depth (present study); $882 \mathrm{~m}$ depth (Laubitz 1977).

Distribution. Japan: off Namie Town, Fukushima Prefecture (present study). USA: off the Near Islands in the Aleutian Islands, Alaska (Laubitz 1977).

\section{Metadulichia gen. nov.}

[Japanese name: Hosonaga-shakutoridoronomi-zoku, new]

Type species. Metadulichia kohtsukai sp. nov., by original designation.

Diagnosis. Body cylindrical, but urosomites depressed dorsoventrally; pereonites 6, 7 fused; urosomites flexed beneath posterior pereonites and pleonites $1-3$, urosomite 1 elongate, much longer than pleonites $2+3$, urosomites 2,3 coalesced, shorter than urosomite 1 . Head triangular, rostrum small. Antennae long, slender; antenna 1 peduncular article 3 longest, accessory flagellum 3-articulate; antenna 2 shorter than antenna 1. Upper lip broad, fleshy, ventral margin bilobed. Mandible, molar large; palp with 3 articles, article 2 longest, article 3 rectolinear. Lower lip with welldeveloped inner lobes, outer lobes each with short mandibular lobe. Maxilla 1 small; inner plate rudimentary, without setae; outer plate bearing 7 terminal robust setae; palp 2-articulate, with 3 robust setae at tip. Maxilla 2 inner plate with single mediofacial seta. Maxilliped inner plate with several short robust setae; outer plate not reaching apex of palp article 2; palp consisting of 4 articles, article 4 with stout seta. Coxae small, short, discontiguous; gills present on coxae $2-5$; oostegites of female unknown. Gnathopod 1 weakly subchelate, rather simple; carpus longer than propodus, carpus-dactylus long. Male gnathopod 2 larger than gnathopod 1, subchelate; carpus much shorter than propodus, propodus wide, posterior margin with proximal and distal projections, palm oblique, dactylus long. Female gnathopod 2 unknown. Pereopods 3, 4 short, subsimilar to each other; basis slender, glandular. Pereopod 5 long; basis and merus linear, propodus without palm. Pereopods 6, 7 unknown. Pleopods large, each with developed peduncle. Uropod 1 slender, biramous, peduncle shorter than both rami, outer ramus shorter than inner ramus; uropod 2 shorter than uropod 1, peduncle shorter than inner ramus, outer ramus extremely shorter than inner ramus; uropod 3 absent. Telson entire, ovate, longer than broad.

Etymology. From the Greek meta (=beyond) and Dulichia (related genus).

Gender. Feminine.

Included species. Metadulichia kohtsukai sp. nov.

Remarks. This new genus is characterized by the small maxilla 1 with 7 terminal robust setae on the outer plate and with 3 robust setae at the tip of palp, the maxilla 2 inner plate bearing single mediofacial seta, and the uropod 2 outer ramus extremely shorter than the inner ramus. These features are unique in the family Dulichiidae.

\section{Metadulichia kohtsukai sp. nov.}

(Figs 14-16)

[Japanese name: Hosonaga-shakutoridoronomi, new]

Material examined. Holotype: male (OMNH-Ar-10824), $3.5 \mathrm{~mm}$, Sagami Bay, southwest of Miura City, Kanagawa Prefecture, $35^{\circ} 06^{\prime} 57^{\prime \prime} \mathrm{N}, 139^{\circ} 33^{\prime} 44^{\prime \prime} \mathrm{E}-35^{\circ} 06^{\prime} 43^{\prime \prime} \mathrm{N}, 139^{\circ} 34^{\prime} 03^{\prime \prime} \mathrm{E}$ (Fig. 1E), 230-398 $\mathrm{m}$ depth, using dredge, 10 December 2015, coll. H. Kohtsuka.

Diagnosis. Eyes ovate. Accessory flagellum 3-articulate. Maxilla 1 small, outer plate bearing 7 terminal robust setae,

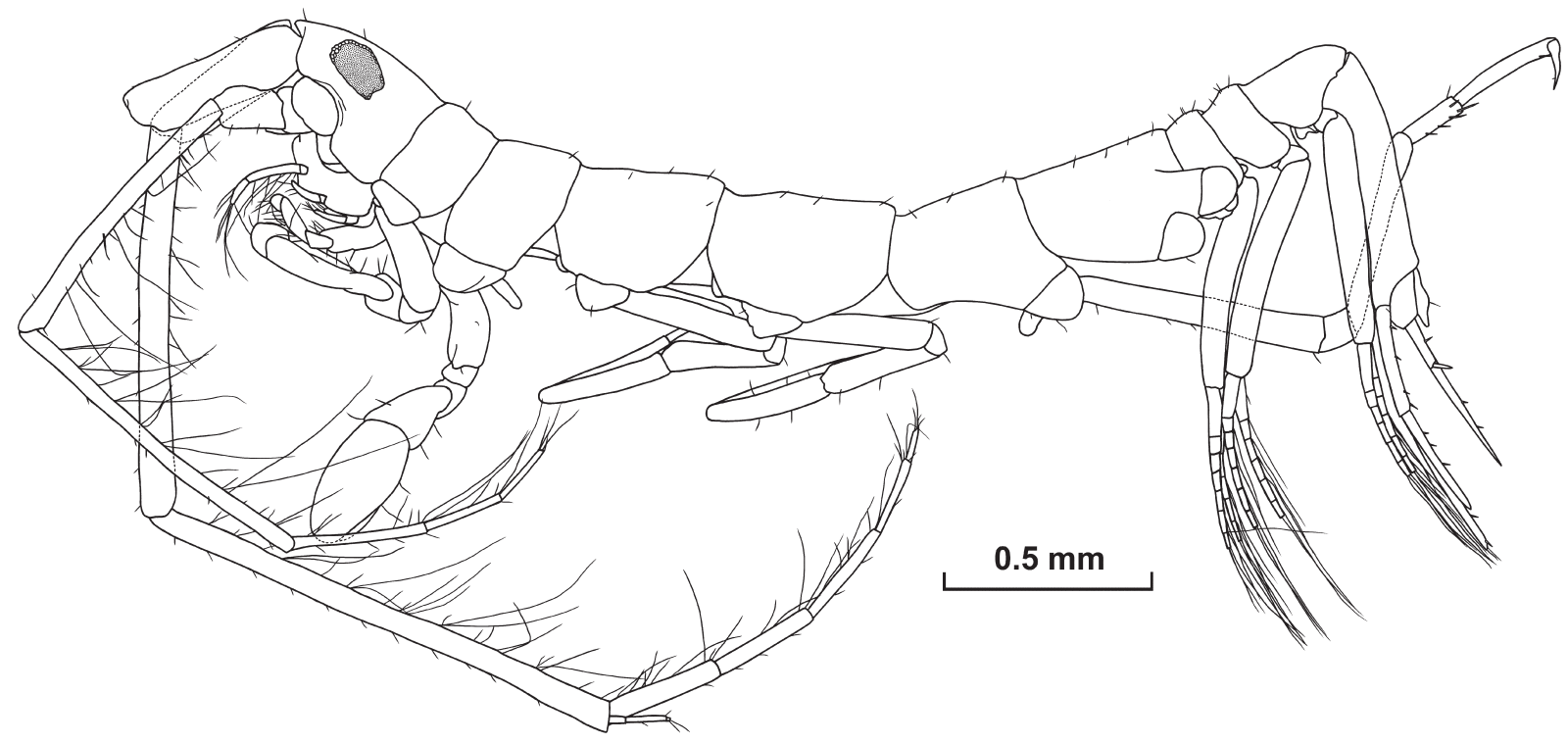

Fig. 14. Metadulichia kohtsukai gen. nov., sp. nov. Holotype, male (OMNH-Ar-10824), $3.5 \mathrm{~mm}$. Habitus, left lateral view, most of left antenna 1 and pereopods 5-7 lost, right antenna 1 and pereopod 5 drawn. 


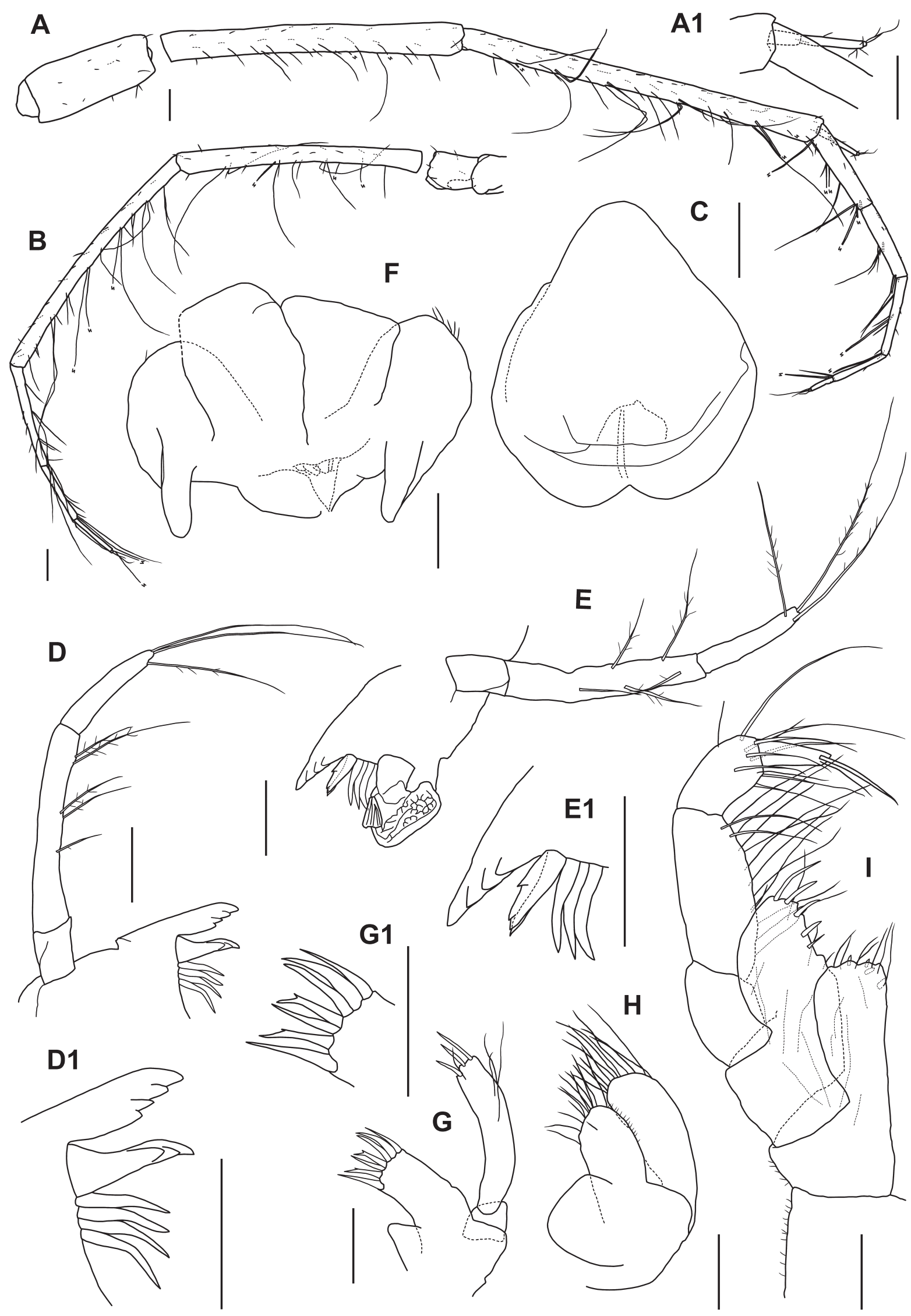

Fig. 15. Metadulichia kohtsukai gen. nov., sp. nov. Holotype, male (OMNH-Ar-10824), $3.5 \mathrm{~mm}$. A, right antenna 1, lateral view; A1, accessory flagellum of right antenna 1 , lateral view; B, left antenna 2, lateral view; $\mathrm{C}$, upper lip, anterior view; D, left mandible, medial view, molar lost; D1, incisor, lacinia mobilis and accessory blades of left mandible, medial view; E, right mandible, medial view; E1, incisor, lacinia mobilis and accessory blades of right mandible, medial view; F, lower lip, ventral view; G, right maxilla 1, dorsal view; G1, distal part of outer plate of right maxilla 1, dorsal view; $\mathrm{H}$, right maxilla 2, dorsal view; I, left maxilliped, dorsal view. Scales: $0.05 \mathrm{~mm}$. 


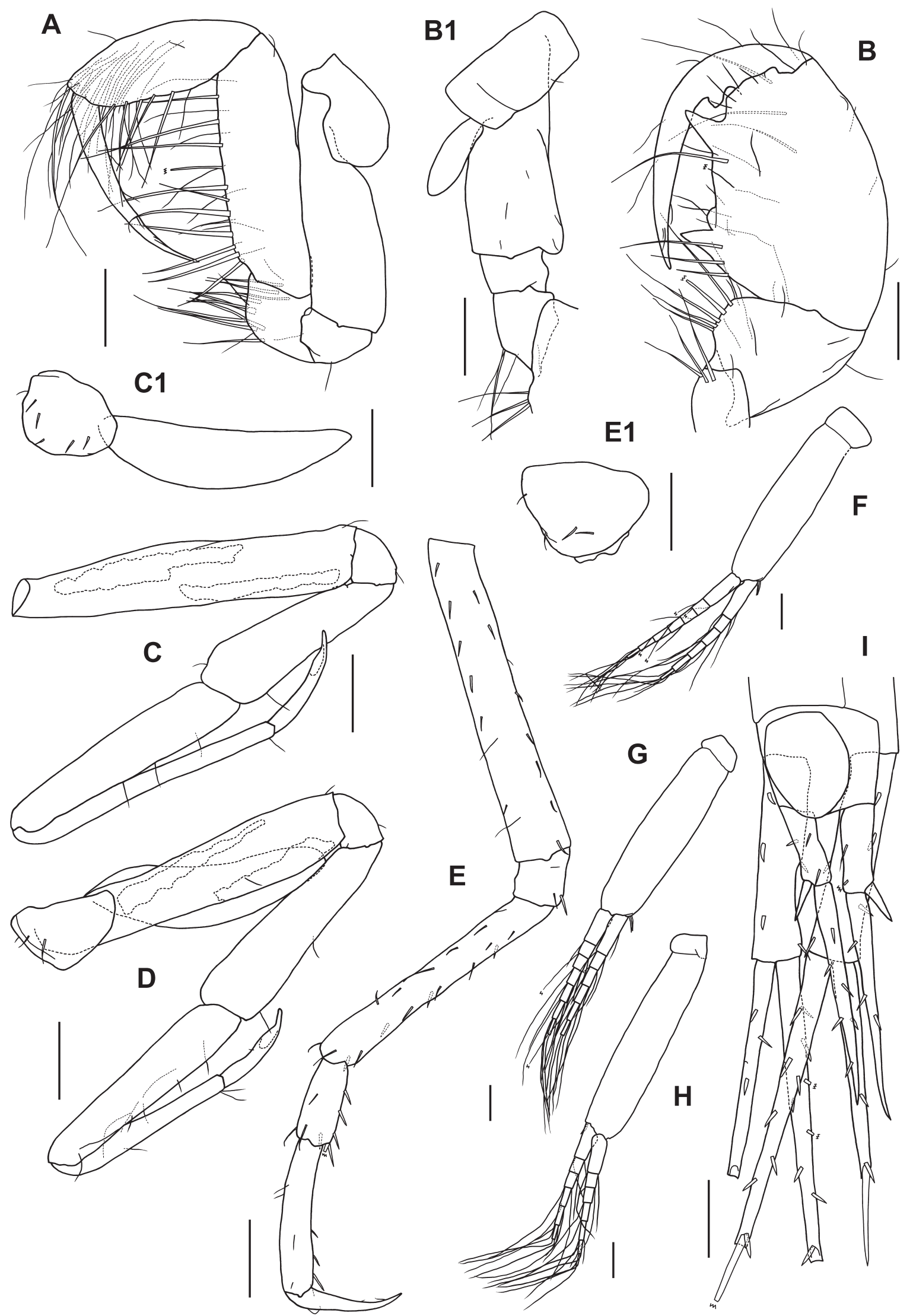

Fig. 16. Metadulichia kohtsukai gen. nov., sp. nov. Holotype, male (OMNH-Ar-10824), $3.5 \mathrm{~mm}$. A, left gnathopod 1, lateral view; B, distal part of left gnathopod 2, lateral view; B1, proximal part of right gnathopod 2, lateral view; C, left pereopod 3, lateral view; C1, left coxa 3 and gill, lateral view; D, left pereopod 4, lateral view; E, right pereopod 5, lateral view; E1, left coxa 5, lateral view, gill lost; F, G, left pleopods 1, 2 , posterior views; $\mathrm{H}$, left pleopod 3, anterior view; I, uropods 1, 2 and telson, dorsal view. Scales: $0.1 \mathrm{~mm}$. 
palp with 3 robust setae at tip. Maxilla 2 inner plate with single mediofacial seta. Male gnathopod 2, basis short, propodus massive, subovoid, posterior margin weakly setose, with small proximal and distal projections and small swelling. Pereopods 3, 4 bases slender. Pereopod 5 elongate, not prehensile. Urosomite 1 about 1.65 times as long as pleonites $2+3$. Uropod 2 outer ramus very short, $17 \%$ as long as inner ramus.

Description of male [based on holotype (OMNHAr-10824), $3.5 \mathrm{~mm}$ ]. Body (Fig. 14) smooth, dorsal margins with sparse short setae, urosomite 1 about 1.65 times as long as pleonites $2+3$. Eyes ovate, about $35 \%$ length of head, composed of many tight ommatidia.

Antenna 1 (Fig. 15A, A1) slender, about same length as body, posterior margin setose; length ratio of peduncular articles 1-3 1.0:2.3:2.8; accessory flagellum short, 3-articulate; primary flagellum with 6 articles, tip minute. Antenna 2 (Fig. 15B) slender, about 0.7 times as long as antenna 1, posterior margin setose; length ratio of peduncular articles 3-5 1.0:7.5:6.3; flagellum with 3 articles. Upper lip (Fig. 15C), ventral margin bare. Mandibles (Fig. 15D, D1, E, E1) with length ratio of palp articles 1-3 1.0:3.6:2.0, articles 2, 3 bearing 5 and 3 setae, respectively; incisor with 4 cusps, lacinia mobilis with 3 cusps, 4 accessory blades present in both sides; molar with spatula-like process in right. Lower lip (Fig. 15F), outer plates with sparse setae apically. Maxilla 1 (Fig. 15G, G1), outer plate with 7 robust setae distally, palp article 2 bearing 3 robust and 1 slender setae distally and 3 slender setae laterally. Maxilla 2 (Fig. $15 \mathrm{H}$ ), inner plate with distal setae, very thin lateral setae and single mediofacial seta; outer plate bearing many setae on distal margin. Maxilliped (Fig. 15I), inner plate with 3 apical and 1 mediodistal short robust setae on ventral surface; outer plate bearing 5 robust setae mediodistally.

Gnathopod 1 (Fig. 16A) relatively slender; coxa with ventral notch; merus setose posterodistally and mediodistally; carpus longer than basis, with many setae on posterior margin; propodus slender, with many setae posteriorly, mediodistal surface heavily setose; dactylus long, slender, curved posteriorly. Gnathopod 2 (Fig. 16B, B1), coxa subrectangular, ventral margin straight, gill small; basis short, anterodistal corner lobate; carpus setose posteriorly; propodus massive, subovoid, about 0.9 times as long as head, about 1.7 times length of carpus, posterior margin weakly setose, with short proximal projection at about $70^{\circ}$ angle to palm, small distal projection at about $50^{\circ}$ angle to palm and small swelling on distal side of proximal projection; dactylus curved posteriorly, posterior margin roundly produced proximally.

Pereopods 3, 4 (Fig. 16C, C1, D) slender, pereopod 3 slightly longer than pereopod 4; coxae triangular, gills long; bases elongate, about 5.2 and 4.8 times as long as width respectively, each with glands in anterodistal and posteroproximal parts; propodi and dactyli narrow. Pereopod 5 (Figs 14, 16E, E1) long; coxa triangular, gill small; basis-carpus with many short robust setae, carpus about 0.55 times as long as propodus; propodus lacking palm, anterior margin bearing 3 robust setae; dactylus long. Pereopods 6, 7 (Fig. 14) lost except for coxae.
Pleopods (Fig. 16F-H), peduncles progressively longer, each with 2 slender coupling hooks; outer rami slightly longer than inner rami, outer rami with 7, 7, 6 articles respectively, inner rami each with 6 articles. Uropod 1 (Fig. 16I), peduncle with 3 lateral and 2 medial robust setae; outer ramus about 0.85 times as long as inner ramus (including distal robust setae), with 2 lateral, 1 medial and 2 distal (long and short) robust setae; inner ramus bearing 2 lateral, 4-5 medial and 2 distal (long and short) robust setae. Uropod 2 (Fig. 16D) about half length of uropod 1 (including distal robust setae); peduncle with 2 medial robust setae; outer ramus very short, $17 \%$ as long as inner ramus, without setae; inner ramus bearing 1-2 lateral and 2 medial robust setae. Telson (Fig. 16D) bare.

Female. Unknown.

Coloration in life. Unknown.

Etymology. Dedicated to Hisanori Kohtsuka of the University of Tokyo for donating many amphipod specimens and their photographs.

Habitat. Bottom sediment unknown, 230-398 m depth.

Distribution. Japan: Sagami Bay (present study).

\section{Key to adult males of Japanese species of the family Dulichiidae}

1. Eyes composed of many dispersed ommatidia, propodi of pereopods 5-7 with palm

Dulichiopsis barnardi Laubitz, 1977

- Eyes composed of many tight ommatidia, propodi of pereopods 5-7 lacking palm

2. Outer ramus of uropod 2 extremely short (less than 0.2 times length of inner ramus)

Metadulichia kohtsukai gen. nov., sp. nov.

- Outer ramus of uropod 2 normal (about 0.8-0.9 times length of inner ramus)

3. Proximal projection of gnathopod 2 palm longer than half of propodus width (body length: longer than $3.5 \mathrm{~mm}$ ), basis of pereopod 4 strongly or weakly expanded (body length: shorter than $4 \mathrm{~mm}$ )

Dulichia biarticulata Hirayama and Takeuchi, 1993

- Proximal projection of gnathopod 2 palm shorter than half of propodus width (body length: longer than $3.5 \mathrm{~mm}$ ), basis of pereopod 4 slightly expanded (body length: shorter than $4 \mathrm{~mm}$ )........ Dulichia latimana sp. nov.

\section{Acknowledgments}

I express my sincere thanks to Dr. Masakazu Aoki of Tohoku University, Osamu Hoshino of the Diving Service Chap, Hisanori Kohtsuka and Masafumi Kodama of the University of Tokyo, Dr. Keisuke Mori of the Hinokuni Benthos Institute, and Dr. Tsuyoshi Takano of the Meguro Parasitological Museum for donating specimens and photographs. I am also grateful to Dr. Ryohei Yamanishi of Nishinomiya Shell Museum and Dr. So Ishida of OMNH who provided equipment, and Dr. James K. Lowry of the Austra- 
lian Museum, Dr. Keiichi Kakui of Hokkaido University and an anonymous reviewer for appropriate comments on the manuscript.

\section{References}

Barnard, J. L. 1964. Some bathyal Pacific Amphipoda collected by the U.S.S. Albatross. Pacific Science 18: 315-335.

Barnard, J. L. and Karaman, G. S. 1991. The families and genera of marine gammaridean Amphipoda (except marine gammaroids). Records of the Australian Museum, Supplement 13 (Parts 1 and 2): $1-866$.

Corbari, L. and Sorbe, J. C. 2018. First observations of the behaviour of the deep-sea amphipod Dulichiopsis dianae sp. nov. (Senticaudata, Dulichiidae) in the TAG hydrothermal vent field (Mid-Atlantic Ridge). Marine Biodiversity 48: 631-645.

Dana, J. D. 1849. Synopsis of the genera of Gammaracea. American Journal of Science and Arts, Series 2, 8: 135-140.

Hirayama, A. and Takeuchi, I. 1993. New species and new Japanese records of the Gammaridea (Crustacea: Amphipoda) from Matsukawa-ura Inlet, Fukushima Prefecture, Japan. Publications of the Seto Marine Biological Laboratory 36: 141-178.

Horton, T., Lowry, J., De Broyer, C., Bellan-Santini, D., Coleman, C. O., Corbari, L., Costello, M. J., Daneliya, M., Dauvin, J-C., Fišer, C., Gasca, R., Grabowski, M., Guerra-García, J. M., Hendrycks, E., Hughes, L., Jaume, D., Jazdzewski, K., Kim, Y.-H., King, R.; Krapp-Schickel, T., LeCroy, S., Lörz, A.-N., Mamos, T., Senna, A. R., Serejo, C., Sket, B., Souza-Filho, J. F., Tandberg, A.H., Thomas, J., Thurston, M., Vader, W., Väinölä, R., Vonk, R., White, K., and Zeidler, W. 2018. World Amphipoda Database. Dulichiidae Dana, 1849. Available at http://www.marinespecies.org/aphia. php? $\mathrm{p}=$ taxdetails\&id $=236746(10$ October 2018$)$
Ishimaru, S. 1985. Methods in the studies of gammaridean Amphipoda. Seibutsu-Kyōzai 19/20: 91-105. [In Japanese]

Krøyer, H. 1845. Karcinologiske Bidrag. Naturhistorisk Tidsskrift, Series 2, 1: 283-345, 403, 453-638, pls 2, 3, 6, 7 .

Laubitz, D. R. 1977. A revision of the genera Dulichia Krøyer and Paradulichia Boeck (Amphipoda: Podoceridae). Canadian Journal of Zoology 55: 942-982.

Laubitz, D. R. 1983. A revision of the family Podoceridae (Amphipoda: Gammaridea). Pp. 77-86. In: Lowry, J. K. (Ed.) Papers from the Conference on the Biology and Evolution of Crustacea (Australian Museum Memoir 18). Trustees of the Australian Museum, Sydney.

Lowry, J. K. and Myers, A. A. 2017. A phylogeny and classification of the Amphipoda with the establishment of the new order Ingolfiellida (Crustacea: Peracarida). Zootaxa 4265: 1-89.

Mattson, S. and Cedhagen, T. 1989. Aspects of the behaviour and ecology of Dyopedos monacanthus (Metzger) and D. porrectus Bate, with comparative notes on Dulichia tuberculata Boeck (Crustacea: Amphipoda: Podoceridae). Journal of Experimental Marine Biology and Ecology 127: 253-272.

McCloskey, L. R. 1970. A new species of Dulichia (Amphipoda, Podoceridae) commensal with a sea urchin. Pacific Science 24: 90-98.

Myers, A. A. and Lowry, J. K. 2003. A phylogeny and a new classification of the Corophiidea Leach, 1814 (Amphipoda). Journal of Crustacean Biology 23: 443-485.

Neretin, N. Y., Zhadan, A. E., and Tzetlin, A. B. 2017. Aspects of mast building and the fine structure of "amphipod silk" glands in Dyopedos bispinis (Amphipoda, Dulichiidae). Contributions to Zoology 86: 145-168.

Nii, H. and Aoki, M. 2005. [Nesting behavior of Dulichia sp. (Amphipoda, Podoceridae) and its ecological significance]. Tsukuba Journal of Biology 4(1). [In Japanese] Available at http://www.biol. tsukuba.ac.jp/tjb/Vol4No1/TJB200501200100778.html (10 October 2018)

Stebbing, T. R. R. 1906. Amphipoda I. Das Tierreich 21: 1-806. 